\title{
CEsifo \\ WORKING

\section{International Corporate Tax Avoidance: A Review of the Channels, Magnitudes, and Blind Spots}

Sebastian Beer, Ruud de Mooij, Li Liu 


\section{Impressum:}

CESifo Working Papers

ISSN 2364-1428 (electronic version)

Publisher and distributor: Munich Society for the Promotion of Economic Research - CESifo $\mathrm{GmbH}$

The international platform of Ludwigs-Maximilians University's Center for Economic Studies and the ifo Institute

Poschingerstr. 5, 81679 Munich, Germany

Telephone +49 (o)89 2180-2740, Telefax +49 (o)89 2180-17845, email office@cesifo.de

Editors: Clemens Fuest, Oliver Falck, Jasmin Gröschl

www.cesifo-group.org/wp

An electronic version of the paper may be downloaded

- from the SSRN website: $\quad$ www.SSRN.com

- from the RePEc website: $\quad$ www.RePEc.org

- from the CESifo website: www.CESifo-group.org/wp 


\title{
International Corporate Tax Avoidance: A Review of the Channels, Magnitudes, and Blind Spots
}

\begin{abstract}
This paper reviews the rapidly growing empirical literature on international tax avoidance by multinational corporations. It surveys evidence on main channels of corporate tax avoidance including transfer mispricing, international debt shifting, treaty shopping, tax deferral and corporate inversions. Moreover, it performs a meta analysis of the extensive literature that estimates the overall size of profit shifting. We find that the literature suggests that, for the most recent year, a 1 percentage-point lower corporate tax rate compared to other countries will expand before-tax income by 1.5 percent-an effect that is larger than reported as the consensus estimate in previous surveys and tends to be increasing over time. The literature on tax avoidance still has several unresolved puzzles and blind spots that require further research.
\end{abstract}

JEL-Codes: F230, H250.

Keywords: corporate taxation, multinationals, profit shifting, international tax avoidance, meta analysis.

Sebastian Beer

Fiscal Affairs Department

International Monetary Fund

USA - 20431 Washington DC

SBeer@imf.org
Ruud de Mooij

Fiscal Affairs Department

International Monetary Fund

USA - 20431 Washington DC

RdeMooij@imf.org

Li Liu

Fiscal Affairs Department

International Monetary Fund

USA - 20431 Washington DC

LLiu@imf.org

July 2018

We thank Jan Brueckner, Vitor Gaspar, Niels Johannesen, Michael Keen, Kun Kim, Joel Slemrod, and participants at the IMF "Evaluating Tax Reform" conference and Fiscal Affairs Department seminar for helpful comments. We are grateful to Jost Heckmeyer and Michael Overesch for sharing their dataset for replication purposes. Any remaining errors are our own. 


\section{INTRODUCTION}

Tax avoidance by multinational corporations (MNCs) has been on top of the international tax policy agenda since the global financial crisis. The tight fiscal constraints in the aftermath of the crisis amplified long-standing concerns in many countries that large MNCs pay very low effective tax rates. Moreover, the revelation of aggressive avoidance schemes in Luxleaks and more recently the Paradise papers have reinforced the public disquiet about the unfairness of the low effective taxation of some MNCs. These concerns have led to major new international initiatives to curb international tax avoidance - most notably the G20/OECD initiative on base erosion and profit shifting (OECD, 2015). Their aim is to develop approaches that limit the opportunities for MNCs to artificially shift profits and thus to enhance revenue mobilization.

This paper offers a survey of the empirical literature on international tax avoidance. The latter is defined as the international reallocation of profits by an MNC in response to tax differences between countries, with the aim to minimize the global tax bill. Hence, we ignore reallocation of real capital in response to tax. This survey goes beyond discussing studies assessing the overall magnitude of profit shifting and include those on the importance of specific channels, especially the most commonly adopted ones such as transfer mispricing, strategic location of intellectual property (IP), international debt shifting, and treaty shopping. It also discusses tax avoidance devices that are unique to worldwide taxation systems, such as corporate inversions/headquarter relocation, and tax deferral. Moreover, it summarizes empirical evidence on the effectiveness of a range of targeted anti-avoidance measures, which have been put in place to curb tax avoidance.

This paper extends earlier literature reviews by e.g. Dharmapala (2014), Hines (2014) and OECD (2015) in three important ways. First, we place a variety of empirical tax avoidance studies into a systematic framework of the current international tax architecture. Second, within this framework, we broaden the review's scope, as the number of studies on tax avoidance has been rapidly expanding in recent years. We survey empirical evidence on six main channels of international tax avoidance.

Finally, we perform a meta-analysis of studies estimating the magnitude of total profit shifting to derive a consensus estimate of the tax sensitivity of MNC's reported profits to tax rates. The meta-analysis extends earlier work by Heckemeyer and Overesch (2017) by almost doubling the sample size of primary estimates, ${ }^{1}$ reducing specification bias, and adopting an enhanced identification approach that corrects for within-study correlation of primary estimates. Our results suggest that a semi-elasticity of reported pre-tax profits with respect to international tax differential of unity is a good reflection of the literature. This means that a 1 percentage point larger tax rate differential reduces reported pre-tax profits of an affiliate by 1 percent. The estimate is larger than the consensus semi-elasticity of 0.8 in Heckemeyer and Overesch (2017). We further complement Heckemeyer and Overesch (2017) by providing new insights into the importance of controlling for the scale of real activities in estimating the consensus semi-elasticity estimate: excluding this control introduces upward bias in the

\footnotetext{
${ }^{1}$ We include 11 additional studies and 199 additional primary estimates.
} 
consensus semi-elasticity by inflating it to around 1.4. Moreover, we find that the semielasticity has increased over time and that a value of around 1.5 applies to the most recent years. The insight is extremely important for the policy debate on profit shifting and for the calibration of models that account for tax avoidance. Using this estimate, we illustrate the revenue impact of tax avoidance for 81 countries.

The rest of this paper is organized as follows. Section II provides a broad overview of international tax avoidance, elaborating on the current international tax architecture, discussing empirical evidence on various avoidance channels, and elaborating on the impact of specific anti-avoidance measures. Section III reviews the literature on the overall size of profit shifting and provides a meta-analysis. It derives a consensus semi-elasticity and illustrates its implications for government revenue. Finally, Section IV discusses a number of puzzles and blind spots in the literature. It points to research that would be needed to further advance our understanding of international corporate tax avoidance in the future.

\section{INTERNATIONAL TAX AVOIDANCE-THE ISSUE}

\section{A. Brief Overview of the International Tax Architecture}

The tax treatment of MNCs is determined by the international tax framework, which is a myriad of domestic legislations and a wide network of bilateral and multilateral tax treaties. The framework relies largely on separate accounting, which means that taxation of an MNC group is at the level of individual subsidiaries that operate in different countries. Each country has a right to tax the income assigned, based on its domestic law and tax treaty obligations.

When can a country tax MNCs? MNCs generate income in two main ways: selling products or services, and investing their cash on hand. The former is typically known as active income, and the latter, passive. The taxing rights of a country over MNC income are based on the source of the income and the residence of the corporate taxpayer.

Source refers to where investment and production take place and is largely determined by the physical presence of labor and/or capital. Certain thresholds must be met to define a permanent establishment (PE), which determines whether a source country can tax a foreign company or not. Residence refers to the place where the company receiving the income is deemed to have its primary location. Common tests for this are where the company is incorporated or effectively managed. Following international convention, source countries have primary taxing rights over the active business income of foreign PEs while residence countries retain the right to tax passive income.

How does a country tax MNC earnings? Two alternative systems determine the taxation of active business income of MNCs. Under a territorial system (used e.g. in Europe and Japan), residence countries exempt foreign earnings of MNCs so that their active business income is only taxed in the source country. Under a worldwide system (used e.g. in the BRICS and until recently the U.S.), the residence country retains the right to tax active income from all source countries. Double taxation is typically avoided by the residence country granting a 
non-refundable foreign tax credit against its own tax, so that the residence tax is limited to the excess of the residence country's effective tax rate over that in the source country.

In practice, the distinction between worldwide and territorial systems is not as clear-cut. Some provisions in existing systems, such as the deferral of dividend tax obligation until repatriation or the use of excess credits from high-tax countries to offset taxes on dividends from low-tax countries (cross-crediting), tend to soften the bite of worldwide taxation (Matheson et al, 2014). Other measures, such as Controlled Foreign Company rules (CFC), extend domestic taxation rights for both worldwide and territorial systems by taxing foreign passive income immediately. ${ }^{2}$

Withholding taxes also blur the clean allocation of passive income between source and residence countries. Many source countries impose withholding taxes on outbound income payments, such as interest, royalties and dividends. While residence countries typically provide some relief through foreign tax credits, unilateral endeavors to prevent double taxation are often imperfect and withholding taxes can "stick" on cross-border income flows. Double tax treaties (DTTs), by specifying maximum withholding tax (WHT) rates which are often lower than the domestic WHT rates and sometimes down to zero, tend to limit source country's taxing right on cross-border passive income flows. ${ }^{3}$ In this context, withholding taxation becomes a bilateral instrument to divide revenues between countries.

\section{B. Main Channels of International Tax Avoidance}

Avoidance of source country taxation. Within the international tax framework, MNCs can use a wide array of techniques to shift profits between entities in the group to minimize their overall corporate tax liability. These techniques can be entirely legal, in which case they are referred to as tax avoidance - as opposed to tax evasion, which is illegal. ${ }^{4}$ The precise channels of tax avoidance can vary, depending on the specific features of national tax

\footnotetext{
2 The 2017 Tax Cuts and Jobs Act (TCJA) has created a hybrid system in the U.S. By exempting foreign earnings of U.S. MNCs from additional U.S. tax upon repatriation, the TCJA has in principle moved the U.S. to territoriality. On the other hand, the TCJA, in the Global Intangible Low Taxed Income (GILTI) provision, imposes a minimum on overseas income that is in excess of 10 percent of the return on tangible assets. Specifically, it taxes at the standard U.S. CIT rate, and on accrual, the income of U.S. CFC's earned in all foreign jurisdictions that exceeds 10 percent of qualified business asset investment (i.e., the depreciated value of tangible fixed assets of those controlled foreign corporations) — but with a deduction for 50 percent of that income. Credit is also given for 80 percent of the foreign tax paid on such income. The effect is to impose a minimum rate of 10.5 percent on GILTI income (when no tax is paid abroad) with the U.S. liability wholly eliminated if the average foreign tax rate paid is at least 13.125 percent. In this respect, the U.S. still maintains some element of worldwide taxation.

${ }^{3}$ Moreover, by stipulating that foreign withholding tax payments are creditable against the domestic tax liability, DTTs often imply that the WHT is irrelevant for the MNC's final tax obligation.

${ }^{4}$ However, the dividing line is often unclear, and there are plenty of cases/disputes in differentiating tax evasion from tax avoidance.
} 
systems and treaty networks. For instance, taxation in source countries can be minimized by; ${ }^{5}$ (i) transfer mispricing (stretching, violating or exploiting weaknesses in the arm's length principle); (ii) strategic location of management of intellectual property (IP) to low-tax countries to reduce taxes on associated income; (iii) debt shifting through intracompany loans (excessive borrowing in high-tax countries and lending to low-tax countries); (iv) treaty shopping (exploiting treaty networks to route income so as to avoid tax); (v) risk transfer (conducting operations in high tax jurisdictions on a contractual basis to limit profits attributable there); (vi) avoiding PE status; and (vii) locating asset sales in low-tax jurisdictions (to avoid taxes on the capital gains).

Avoidance of residence country taxation. Worldwide systems can serve as a backstop for the avoidance of source taxes, since income will ultimately be subject to repatriation taxes in the residence country. However, residence taxation can also be avoided. One way is by the artificial use of tax deferral (delaying payment to the parent, sometimes indefinitely). Alternatively, the firm can avoid resident status through corporate inversion (changing residence to escape repatriation taxes or CFC rules) or by choosing the location of a new residence in a country that operates a territorial system.

The rest of this section reviews existing empirical evidence on the main channels of international tax avoidance. The literature review is confined to channels where available data allows identifying the behavioral effects of the international tax systems. Systematic evidence on other channels is largely absent.

\section{Transfer Mispricing}

The valuation of intra-company transactions within an $\mathrm{MNC}$ affects the global allocation of the tax base between source and residence countries. Most countries use the arm's length principle, which stipulates that internal prices between related parties should resemble prices that would prevail between independent parties. Yet, despite extensive OECD and UN Guidelines, there may be significant room for subjective interpretation. Conceptually, there may even be no "correct" arms-length price if there are no comparable third-party transactions. Given these weaknesses in the implementation of the arms-length' principle, MNCs may be able to charge artificially low prices for exports sold from high-tax to low-tax countries, or artificially high prices for inputs coming from low-tax countries, to reduce their global tax liability. ${ }^{6}$

The literature provides ample evidence for the presence of tax-motivated transfer mispricing. Earlier empirical studies show that at the aggregate level, differences in the statutory corporate tax rate between the US and its trading partners substantially influence the balance and pattern of intra-firm trade in the US (Clausing, 2001, 2006). Later studies provide more

\footnotetext{
5 Taxes in high-tax locations can also be avoided by changing the location of foreign direct investment (FDI). This paper, however, focuses only on tax avoidance through profit shifting, not through a change in the location of real capital (for a survey of taxation and FDI, see e.g. De Mooij and Ederveen 2008).

${ }^{6}$ Transfer mispricing has also implications for national accounts statistics and the measurement of GDP growth, see e.g. Guvenen et al (2017).
} 
direct evidence, showing that the price wedge between the arm's-length price for unrelated transactions and the transfer price for related-party transactions varies systematically with corporate tax rate differentials faced by MNCs in the U.S. (Clausing, 2003; Bernard et al, 2006; Flaaen, 2016), Denmark (Cristea and Nguyen, 2016), France (Davies et al., 2017), Germany (Hebous and Johannesen, 2015), and the UK (Liu et al, 2017). The size of the effect, however, differs between studies, reflecting possible differences between countries, sectors and firms, as well as in the empirical sample and estimation methods. Overall, the estimated semi-elasticity (i.e. the percentage increase in the transfer price of exports in response to a 1 percentage point reduction in the tax rate differential to lower-taxed countries) ranges between 0.5 and 6 .

\section{Strategic Location of IP}

Another way to reduce the global tax of an MNC is by strategically moving valuable IPs to low-tax affiliates. Companies can conduct their research and development (R\&D) activities in one country, but transfer the ownership of the patent that is subsequently created to another country where the resulting income streams will be taxed at a lower rate. ${ }^{7}$ As, there is often no comparable transactions of IPs between unrelated parties, determining the arm's length price for company's intangible transactions is usually very difficult, leaving room for tax-induced manipulation of transfer prices (see e.g. Grubert, 2003; Desai et al, 2006).

Empirical evidence concurs that the location of valuable IP is systematically distorted toward low-tax locations, by documenting a negative association between the level of corporate tax rate and the probability of patent application and the subsidiary's level of IPs in one country. Specifically, using a panel data set of multinational affiliates within the EU-25 between 1995 and 2005, Dischinger and Riedel (2011) find that a decrease in the average tax difference to all other affiliates by one percentage point raises the subsidiary's level of IP by 1.6 percent. Using data on corporate patent holdings of European MNCs, Karkinsky and Riedel (2012) find that a one percent point increase in the corporate tax rate reduces the probability of patent applications by around 3.5-3.8 percent. Tax-responses of IP locations are found to be heterogeneous across European countries (for instance, due to differences in market size or enforcement) ${ }^{8}$, with the amount of patents held most sensitive to tax in Luxembourg (with an estimated tax semi-elasticity of 3.9) and least sensitive in Germany (with an estimated tax semi-elasticity of 0.5) (Griffith et al, 2014). Empirical evidence using data on European and US patent and trademark applications during 1996-2012 also suggests that there is substantial difference in the tax-responses of IP locations between types of IP (Dudar and Voget, 2016), where the estimated tax semi-elasticity of trademarks is -6.2 and is significantly larger than that of patents (with an average tax semi-elasticity of -1.9), as generation of the latter is likely to be tied with some real $\mathrm{R} \& \mathrm{D}$ activities.

\footnotetext{
${ }^{7}$ Relocation of such intangibles commonly take place before they are fully developed (and the value is fully known to the tax authority) to avoid capital gains tax on the initial transfer.

${ }^{8}$ Theoretically, smaller countries may be expected to have relatively high own tax elasticities, as a change in their tax rate will not affect the market rate of return, making the cost of capital more responsive to tax changes.
} 


\section{International Debt Shifting}

A third way for an MNC to reduce its tax bill is through intracompany loans. Cross-country differences in rates of CIT create opportunities for lending from low-tax countries to affiliates in high-tax countries or by locating external borrowing in high-tax countries. This debt shifting reduces the group's tax bill without affecting the overall debt exposure of the group (and hence its bankruptcy risk).

Empirical studies confirm the presence of debt shifting, by showing that host-country taxes or international tax differentials have a positive and significant effect on internal debt of German MNCs (Weichenrieder, 1996; Ramb and Weichenrieder, 2005; Overesch and Wamser, 2006; Mintz and Weichenrieder, 2010; Schindler et al., 2013; and Buettner and Wamser, 2013), on intrafirm interest and debt ratio of U.S. MNCs (Grubert, 1998, Altshuler and Grubert 2003; Desai et al, 2007), and on internal leverage of MNCs in Europe (Huizinga et al, 2009). Synthesizing this literature in a meta analysis, De Mooij (2011) finds that the tax elasticity of intra-company debt is 0.5 , which based on an average ratio of intra-company debt-to-assets of 0.24 in the meta sample, corresponds to a tax impact on the internal debtasset ratio of 0.12 . Debt shifting is found to be more pervasive in developing countries, with the effect of taxes twice as large as in developed economies (Fuest et al, 2011).

\section{Tax Treaty Shopping}

Considerable variation in the WHT rates in more than 3000 bilateral DTTs creates opportunities of treaty shopping. This enables MNCs to link different DTTs and divert crossborder payments through the country with the lowest WHT rate.

Empirical evidence for treaty shopping is first documented by Weichrieder and Mintz (2008), who show that higher bilateral WHTs to (from) Germany increase the probability that outward (inward) FDI is diverted via a third country. The link between lower WHT rates and re-routing of FDI is further supported in Weyzig (2013), who shows that the reduced WHT rate on dividend payments in Dutch tax treaties is the key driver of FDI diversion through Dutch Special Purpose Entities. Revenue losses associated with treaty shopping can be substantial for source countries. Beer and Loeprick (2018) find that treaty-shopping has reduced CIT revenues in Sub Saharan Africa by around 15 percent among countries having signed a treaty with an investment hub. Balabushko et al. (2017) show that reduced WHTs under the Ukraine-Cyprus DTT imply revenue losses of around US \$77 million for Ukraine in 2015, or one percent of CIT revenue.

\section{Tax Deferral}

As worldwide taxation imposes residence tax only upon repatriation of the profit, MNCs can avoid repatriation taxes by retaining foreign earnings abroad. The tax deferral channel is different from the others in that with an unchanging tax rate, deferral affects only the present value of taxes paid instead of the total revenue. Moreover, theory predicts that, tax deferral may or may not be a relevant avoidance strategy. Analogous to the "new view" of dividend taxation, Hartman (1985) argues that dividend taxes are unavoidable costs for mature foreign 
subsidiaries, i.e. at some point in time they must be paid. Hence, if the subsidiary's choice is to distribute dividends now or later and taxation remains constant, the tax rate should play no role. However, effects are expected if tax rates are anticipated to change. Several empirical papers find support for tax deferral, by showing that US MNCs increase their dividend payout in response to lower taxes on repatriation (Hines and Hubbard, 1990; Altshuler and Newlon,1993; Grubert,1998; Altshuler and Grubert, 2003). Recent studies, exploiting UK's and Japan's adoption of a territorial system in 2009 in a quasi-experimental setting, provide similar evidence that exemption of foreign earnings boosted dividend repatriation in the UK (Egger et al, 2015) as well as in Japan (Hasegawa and Kiyota, 2017).

\section{Corporate Inversions and HQ Location}

MNCs in worldwide countries can also avoid repatriation taxes by changing the residence of the corporation or, stated differently, by "inverting" roles in the corporate group. ${ }^{9}$ Corporate inversion by US parents are generally associated with substantial tax savings (Desai and Hines, 2002). Using a dataset of 60 US MNCs that restructured between 1983 and 2015, CBO (2017) finds that the average saving in each company's global corporate taxes is around US \$45 million in the year after the inversion.

More broadly, corporate inversions are a special case of cross-border mergers and acquisitions (M\&As) that are influenced by tax considerations. Using data on 278 crossborder M\&As between 1997 and 2007, the taxation of foreign passive income in CFC legislations and worldwide taxation of foreign active income are found to be major drivers for cross-border M\&As (Voget, 2007; Huizinga and Voget, 2009).

\section{How Effective are Anti-Avoidance Regulations?}

During the last few decades, countries have adopted various anti-avoidance regulations to mitigate tax avoidance by MNCs. These include, for example, the adoption of transfer pricing regulations, thin capitalization rules, controlled foreign corporations (CFC) rules or a general anti-avoidance rule (GAAR). These efforts have received considerable attention in light of the G20-OECD initiative on BEPS. For instance, countries participating under what is now called the inclusive framework on BEPS, commit to four minimum standards (e.g. on treaty abuse) and adhere to the common approaches to adopt anti-avoidance legislation. The European Union has also adopted an anti-tax-avoidance directive that requires its member states to implement a common set of rules to address tax avoidance. This section reviews the studies that analyze the effectiveness of anti-avoidance rules.

Transfer Pricing Regulations offer guidance in the implementation of the arm's length principle. They often specify the methods that can be used to calculate transfer prices, determine documentation requirements, include various specific requirements in its application needed to support the transfer prices used, and set penalties if mispricing is

\footnotetext{
${ }^{9}$ Corporate inversions can take the form of a merger with a foreign entity, which then results in the former domestic parent becoming a subsidiary of the new foreign parent (even though the shareholders of the original domestic company may retain more than 50 percent of the shares in the new corporation).
} 
detected or adequate documentation is not provided. Their effectiveness in curbing international tax avoidance is supported in two concurrent studies, which show that introduction and tightening of transfer pricing rules can diminish the tax sensitivity of corporate profits by 50 percent (Riedel et al, 2015), though with much weaker effects for firms with many intangible assets or complex group structures (Beer and Loeprick, 2015). A later study shows that stricter regulations reduce reported profits of MNCs, possibly due to the combination of lower profit inflows into countries that are intermediate hubs for profit shifting and higher compliance costs of MNCs (Saunders-Scott, 2013). ${ }^{10}$

Thin Capitalization Rules deny interest deductibility above a certain threshold of either net interest payment (as a ratio of income) or net debt (as a ratio to equity). The precise conditions under these rules vary between countries and over time. Empirical evidence suggests that, on average, well-designed thin capitalization rules are effective in reducing debt shifting by multinationals, using data for MNCs in Germany (Overesch and Wamser, 2010; Buettner et al, 2012) and the U.S. (Blouin et al, 2014).

CFC Rules stipulate that foreign subsidiaries' income are subject to domestic taxation without deferral if certain conditions are met. CFC rules thus expand domestic taxation rights of territorial systems and limit the impact of deferral under worldwide systems. Initial studies have exploited the German MiDi dataset and find that CFC legislation reduces passive assets by 77-82 percent for subsidiaries where the legislation was binding, i.e. for whom the statutory tax rate in their host country falls below the safe-haven tax rate (Ruf and Weichenrieder, 2012). A recent study confirms this finding, by contrasting the financial earnings of subsidiaries in 200 countries just above and below the tax rate threshold; it reports a 20 percent difference in the level of reported profit due to binding CFCs (Clifford, 2017).

\section{A NeW CONSENSUS ON TAX-MOTIVATED PROFIT SHIFTING}

The research reviewed in the previous session examines channels of international tax avoidance separately. In contrast, following a simple conceptual framework developed by Hines and Rice (1994), and extended by Huizinga and Leaven (2008), a wide body of empirical work has examined the overall extent of tax-motivated profit reallocation by estimating the following regression:

$$
\log \left(\pi_{i}\right)=\varepsilon\left(\tau_{i}-\bar{\tau}\right)+\gamma^{\prime} X_{i}+\omega_{i}
$$

where $\pi$ is a measure of reported profit before taxation in country $i,\left(\tau_{i}-\bar{\tau}\right)$ is a tax rate differential, $X$ is a vector of control variables, and $u$ is an idiosyncratic error term. The tax rate differential measures the difference in statutory CIT rate between location $i$ and the average CIT rate among other affiliates of the same company group. The tax coefficient $(\varepsilon)$ captures the responsiveness of reported profits to the tax rate differential, and is expected to

\footnotetext{
${ }^{10}$ Another explanation could be that stricter transfer pricing rules increase the effective marginal tax rate, and therefore dampen MNC investment (De Mooij and Liu, 2018).
} 
be negative in the presence of profit shifting. The vector of controls, $X$, typically includes real variables, such as capital and labor inputs, to avoid confounding effects of tax on profit shifting and real production.

The typical study estimates equation (1) by using firm-level data. However, some studies use more aggregate data to infer a relationship between taxable profits and tax rate differential. Micro studies on profit shifting only capture avoidance behavior that affects the observed profits of a MNC. While transfer mispricing, international debt shifting, and strategic location of IPs directly effects reported profitability, other avoidance channels are not necessarily captured in studies using variants of equation (1). For instance, avoidance of PE status implies that there is no profit reported in the first place, suggesting that micro studies that exploit firm-level data would neglect this channel. ${ }^{11}$ Alternatively, avoidance of dividend taxes on repatriation would change after- but not before-tax profits, and would not be captured in either macro or micro studies. Macro studies may capture a wider range of profit shifting channels related to statutory CIT rate differential. Yet, by exploiting variation in the statutory CIT rates, all studies neglect avoidance of other corporate taxes, including those on interest, royalty and service fees, or on capital gains tax (treaty shopping and offshore indirect transfer of assets).

Empirical estimates of the semi-elasticity vary widely. Part of this dispersion is structural, as costs of profit shifting are likely to differ across MNCs of different operating scale or industry structure, and across countries with varying enforcement and administrative capacity. Given these differences, we expect variability in the estimates from different studies even with the same regression specification. Part of the dispersion in the estimated semi-elasticity, however, is study-specific. For example, early studies often use crosssectional data at the country level, and rarely control for real determinants of economic profitability. More recent studies use micro-level panel data and control for a wide range of non-tax determinants of profits at both the macro and firm level.

This section uses meta regressions to synthesize existing empirical evidence on profit shifting, and to disentangle the drivers behind reported estimates. Specifically, we first construct a comprehensive dataset that includes 402 estimated semi-elasticities of reported profit with respect to a tax measure, associated standard errors, and a range of specificationand study-specific variables. We then use a meta regression to uncover the "consensus estimate", which represents the most likely value of the true semi-elasticity based on all evidence currently available. ${ }^{12}$

\section{A. Data and Descriptive Statistics}

We identify relevant studies in a comprehensive search of the EconLit database, economic journals, and working paper platforms, such as SSRN, using the keywords "income shifting",

\footnotetext{
${ }^{11}$ Avoidance of PE would be captured though, in macro-studies that use national accounts.

12 Throughout this section, we report the absolute value of this semi-elasticity (i.e. as a positive value, even though this reflects a negative effect of reported profit to the tax rate).
} 
"profit shifting" and "tax avoidance". ${ }^{13}$ We include studies that use a profit measure as the dependent variable and that either directly produce tax semi-elasticities or allow for their imputation. Our baseline sample has 402 semi-elasticities from 37 papers: ${ }^{14}$ the earliest study Hines and Rice (1994) uses cross-sectional data in 1982; the latest Dowd et al., (2017) uses micro-level panel data up to the year 2012.

Table 1. Estimated Semi-Elasticity of Pre-Tax Profits

\begin{tabular}{|c|c|c|c|c|c|}
\hline $\begin{array}{l}\text { Sample } \\
\text { (1) }\end{array}$ & $\begin{array}{r}\text { Mean } \\
\text { (2) }\end{array}$ & $\begin{array}{c}\text { Weighted Mean } \\
\text { (3) }\end{array}$ & $\begin{array}{c}\text { Median } \\
\text { (4) }\end{array}$ & $\begin{array}{c}\text { Observations } \\
\text { (5) }\end{array}$ & $\begin{array}{c}\text { Number of } \\
\text { underlying } \\
\text { studies } \\
\text { (6) }\end{array}$ \\
\hline Baseline & 1.59 & 0.79 & 1.05 & 402 & 37 \\
\hline $\begin{array}{l}\text { No conditional } \\
\text { estimates }\end{array}$ & 1.54 & 0.79 & 1.01 & 294 & 35 \\
\hline $\begin{array}{l}\text { Heckemeyer and } \\
\text { Overesch (2017) } \\
\text { sample }\end{array}$ & 1.47 & 0.79 & 1.00 & 208 & 26 \\
\hline $\begin{array}{l}\text { Peer-reviewed, } \\
\text { micro-data sample }\end{array}$ & 1.38 & 0.72 & 0.99 & 269 & 22 \\
\hline
\end{tabular}

Notes: This table reports the summary statistics of the semi-elasticity estimates in four different samples in column (1). Weighted mean is computed as the average of semi-elasticity estimates weighted by the inverse squared standard error.

Table 1 summarizes features of the semi-elasticities in four subsamples of the main dataset (column 1, differences described below). Column 2 shows the mean semi-elasticities. The average semi-elasticities of 1.58 in the baseline sample suggests that reported profit decreases by 1.59 percent in response to a one percentage point increase in the statutory tax rate. Simple averages, however, ignore imprecisions in the primary estimates. Following HO, column 3 summarizes the weighted averages of estimated semi-elasticities by weighting each estimate with its inverse squared standard error, and shows a much smaller average response of 0.79 for the baseline sample.

Baseline sample. Our baseline sample expands the HO sample in two important ways. First, it includes more studies of profit shifting. Second, it includes more estimates from the same studies included in HO. ${ }^{15}$ Several papers investigate how profit shifting varies with some other explanatory variables $(z)$, such as the presence of mandatory documentation requirements or the intangible intensity of the firm, typically in regressions of the form:

\footnotetext{
${ }^{13}$ Our search took place in February 2018 and focused on both accounting and economic studies. The metaanalysis fully follows the Journal's reporting guidelines as summarized in Stanley et al (2013).

${ }^{14}$ See Appendix 1 for detailed descriptions of the baseline sample.

${ }^{15}$ One exception is that we do not include 12 estimates presented by Loretz and Mokkas (2015), which by regressing after-tax profitability on domestic tax rate introduces mechanical negative correlation between the two variables.
} 


$$
\log \left(\pi_{i}\right)=\beta_{1}\left(\tau_{i}-\bar{\tau}\right)+\beta_{2} z\left(\left(\tau_{i}-\bar{\tau}\right)+\gamma^{\prime} X+\omega_{i} .\right.
$$

To avoid loss of information, we compute average conditional semi-elasticities as $\beta=\left(\beta_{1}+\right.$ $\beta_{2} z$ ), evaluated at the mean value of $z$. The associated standard errors are computed using the delta method.

Sample without conditional estimates. When dropping conditional elasticities from the baseline sample, we lose around one quarter of observations. The mean estimate is 1.54 and slightly smaller to the average in the baseline sample, while the weighted average and median are almost identical.

HO (2017) sample resembles the data used in their study, with similar mean and median values of the estimated semi-elasticity. ${ }^{16}$ Minor differences occur because we use estimates based on updated or published versions of the primary studies.

Peer-reviewed micro-data sample includes 269 semi-elasticity estimates from 22 peerreviewed papers that exploit micro-level data. The mean, weighted-average and median semi-elasticity estimate in this sample is $1.38,0.72$, and 0.99 , respectively.

Figure 1. Semi-Elasticity Estimates over Time

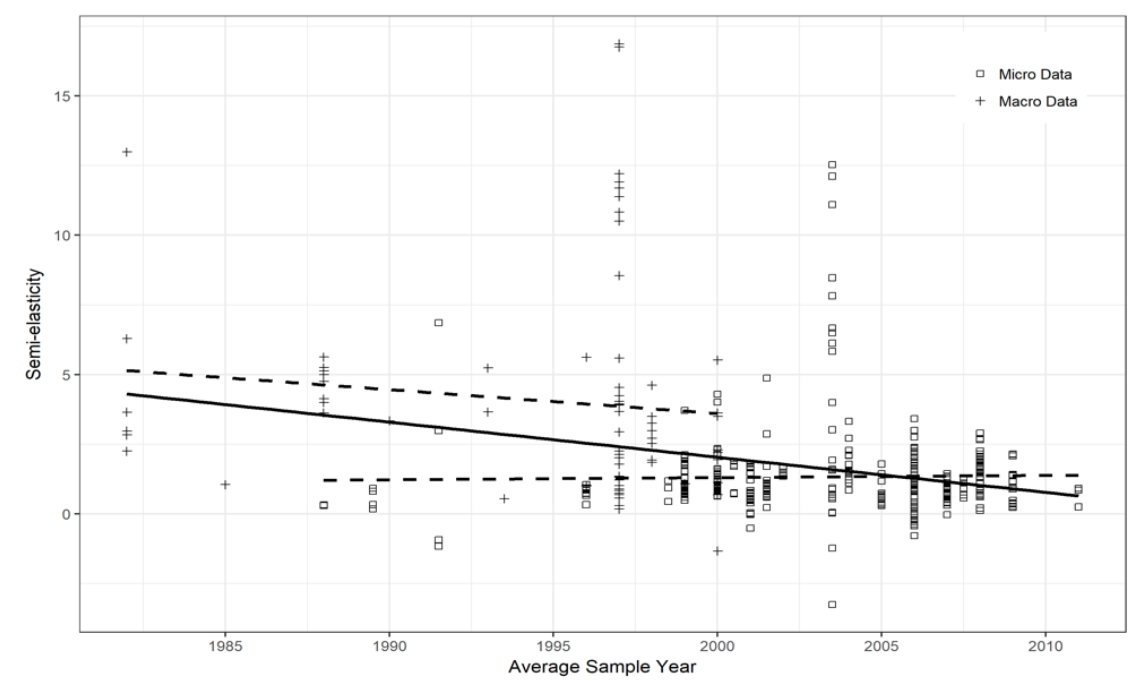

Notes: the crosses show estimated semi-elasticities using macro-data; the squares show estimated semielasticities using micro-data. The solid line is an aggregate time trend; the dotted lines differentiate between micro- and macro-based estimates.

Figure 1 illustrates semi-elasticities of the baseline sample by the average sample year of the underlying study. On average, reported estimates (solid line) have decreased over time. This may reflect a reduced tax response over time. Alternatively, the declining trend may also reflect the more extensive use of granular data (i.e. firm-level panel instead of country-level cross-sectional data) or improved empirical strategies. We further explore the impact of these characteristics on the consensus estimate in the meta-analysis.

\footnotetext{
${ }^{16} \mathrm{HO}$ found an arithmetic mean and median of 1.52 and 1.02, respectively, in a set of 203 observations from 27 studies. Our sample include all the studies from the HO (2017) except Loretz and Mokkas (2015).
} 


\section{B. Synthesis of Primary Estimates: Meta-Regression}

Benchmark Specification. Measured semi-elasticities differ due to structural differences in the underlying sample and differences in the estimation strategy. To disentangle these, we estimate a meta-regression of the form:

$$
\widehat{\varepsilon_{l j}}=\varepsilon+\beta^{\prime} X_{i j}+\omega_{i j,}
$$

where $\widehat{\varepsilon_{l J}}$ is the $i^{\text {th }}$ semi-elasticity reported in study $j$, the vector $X_{i j}$ comprises a set of dummy variables that take the value of one if estimate $j$ in study $i$ deviates from the benchmark specification, and $\omega_{i j}$ is an error term. The intercept $\varepsilon$ thus captures the true semi-elasticity while the coefficients on $X_{i j}$ indicate deviations from this consensus estimate due to study- and estimate-specific attributes. Specifically, $X_{i j}$ includes four groups of study or estimation characteristics:

Estimation techniques and data features: Despite more use of micro-datasets in recent studies, researchers continue to exploit macro data due to its broader coverage in time and geography. Time-series of aggregate data help revealing long-run tax elasticities, as it often takes time for MNCs to restructure their transaction or financing arrangement in response to tax changes. Aggregate data also have obvious drawbacks: profit shifting incentives at the affiliate level are unobservable, factor inputs cannot be matched with reported profitability, and unobservable factors at the firm-level cannot be controlled. ${ }^{17}$

Our preferred specification uses micro-data and controls for firm- and country-specific fixed effects. The indicator Aggregate Data takes the value of one for studies using country-level data; the indicators No Firm FE and No Country FE, take the value of one if the study does not control for unobservable characteristics that differ across firms or countries, respectively.

Dependent variable characteristics: The distribution of firm profitability is heavily skewed and may not fit with a linear regressions model. Previous work addresses this issue in two ways: (1) dropping observations with negative profits and using the natural logarithm of profits as a dependent variable, or (2) using a profitability ratio, such as return on sales or return on assets, as the dependent variable. However, limiting the sample to firms with positive profitability might induce bias as loss making entities are potentially among the most aggressive tax planners (see e.g. Johannessen et al, 2017). ${ }^{18}$ While using a profitability ratio may alleviate this bias, it may capture real responses to the tax rate in the denominator, confounding tax-minimization responses with real ones.

\footnotetext{
${ }^{17}$ Another drawback of the BEA dataset, a major information source for macro studies, is that reported earnings include dividend income. This raises concerns about double counting (Clausing, 2016)

${ }^{18}$ On the other hand, tax law asymmetries (such as loss-offset) imply that loss making entities are subject to a different tax treatment and tax avoidance incentives might differ as a result (Dhamapala, 2014).
} 
Against this background, our preferred specification uses the logarithm of reported profit before taxation as dependent variable. The dummy variable Ratio takes the value of one for studies using profitability ratios instead of the logarithm. The expected effect of this indicator is ambiguous as it depends on the denominator's response to tax differentials. The dummy variable EBIT takes the value of one for studies using before financing profit as the dependent variable. As before-financing profits excludes tax avoidance through internal borrowing, we expect the coefficient of EBIT to be negative.

Tax variable characteristics: From a theoretical perspective, the tax rate variable should capture the net tax savings associated with a relocation of one dollar across the corporate group. Micro-level data often allows computing statutory tax rate differentials that are likely good approximations to this theoretical concept. Absent detailed ownership information, researchers typically use the host country's statutory tax rate. Several studies, particularly from the US, use backward looking average effective tax rates. These rates are outcomes of past profit shifting behavior and raise reverse causality concerns.

Absent special tax regimes and tax holidays, statutory corporate tax rates are precisely the rates applying to the marginal unit of profits and thus capture the true incentive for profit shifting (Devereux, 2007). Our preferred specification uses a statutory tax rate differential. The dummy SingleRate takes the value of one for studies using a single tax rate. The indicator Effective takes the value of one for studies relying on effective tax rates instead of statutory corporate tax rates. We expect the indicator SingleRate to have a negative sign due to attenuation bias. Given the reverse causality between reported profit and effective tax rates (that is, low levels of reported profits after shifting imply a low effective tax rate, generating a spurious positive correlation between the two variables), we expect a positive sign on the indicator Effective.

Controlling for real activity and leverage. Part of the variation in reported profits are due to changes in economic profits, which depend on the scale of real activities. Excluding controls for real activies, the estimated tax elasticity is the elasticity of total taxable income that encompasses both real and reporting responses.

Our benchmark study controls for real production inputs, but not for debt, as internal financing decisions are one channel of profit shifting. Accordingly, the indicator NoReal takes the value of one for studies that do not control for either assets, the number of employees, or payroll, and is expected to have a positive sign. The indicator Debt takes the value of one for studies that hold financing decisions constant (by including leverage decisions as an explanatory variable). We expect the coefficient on Debt to be negative as it excludes an important channel of profit shifting through debt shifting.

Other sample characteristics. We include the average sample year of the underlying study (Z-MIDYEAR) to investigate whether the observable extent of profit shifting has changed over time. ${ }^{19}$ The expected sign of this variable is ambiguous: while growing importance of

\footnotetext{
${ }^{19}$ The Z-MIDYEAR variable is standardized, reflecting deviation from the average sample year of all studies in the baseline sample.
} 
intangible assets and increasingly sophisticated tax planning strategies may indicate a larger tax sensitivity of the global tax base, strengthened anti-avoidance measures may add to the costs of profit shifting to the MNC.

\section{Efficient Estimation}

Researchers typically account for the varying precision of primary estimates by estimating meta-regressions with Weighted Least Squares (WLS). By using the inverse of the reported standard error as a weight, this estimation strategy gives more weight to more accurately measured observations and should thus increase estimation efficiency over OLS.

The efficiency gains of WLS depend on the correct specification of the error structure. Notably, WLS rules out correlation of primary estimates at the study level, which seems to be a restrictive assumption in our context. For instance, studies focusing on intangible intensive firms likely find larger semi-elasticities than studies focusing on publicly-owned manufacturing firms. Such differences would imply correlation of estimates at the study-level and render WLS a less efficient estimation strategy.

We allow for correlation of primary estimates at the study-level to increase the efficiency of our estimates. More specifically, we assume that the unobservable error component of semielasticity $\mathrm{j}$ in study $i$ is given by,

$$
\omega_{i j}=u_{i}+v_{i j}
$$

where $u_{i}$ is study-specific and $v_{i j}$ is estimate-specific. The study- and estimate-specific error components are independently distributed with mean zero and variances $\sigma^{2}$ and $\sigma_{i j}{ }^{2}$.This formulation allows sample characteristics, such as the underlying industry-composition or strength of country-specific anti-abuse measures, to drive the tax sensitivity of reported profits.

We implement the estimations in a two-stage approach. In the first stage, we use OLS on study-specific average values of all dependent and independent variables ${ }^{20}$ to obtain the residuals $\omega_{i}=u_{i}+1 / K_{i} \sum_{j} v_{i j}$, where $K_{i}$ is the number of point-estimates provided in study $i$. Note that primary studies derive estimates conditional on study-specific characteristics. Reported standard errors thus directly provide information on the estimate-specific component $\sigma_{\mathrm{ij}}^{2}=\operatorname{Var}\left(\widehat{\varepsilon_{l j}} \mid X, u_{i}\right)$. We infer the second component using

$$
\widehat{\sigma^{2}}=\frac{1}{N-V} \sum_{i} \omega_{i}^{2}-\frac{1}{N} \sum_{i} \frac{1}{K_{i}^{2}} \sum_{j} \sigma_{\mathrm{ij}}^{2}
$$

Where $\mathrm{V}$ is the number of control variables included in the regression. In the second step, we combine these estimates to construct the covariance matrix for a feasible generalized least squares (GLS) estimation.

\footnotetext{
${ }^{20}$ Typically referred to as "between" estimation in a panel data context.
} 
A critical advantage of the GLS is that the weight given to any observation depends on the total number of estimates in a study: each observation tends to receive less weight if the underlying study provides many estimates; it receives more weight if the underlying study provides only a few estimates. This makes intuitive sense with intra-study correlation, as the first estimate of an additional study adds more new information to the true semi-elasticity than the $45^{\text {th }}$ estimate of the same study. In contrast, WLS weighs observations solely based on the reported standard error, neglecting the underlying information source.

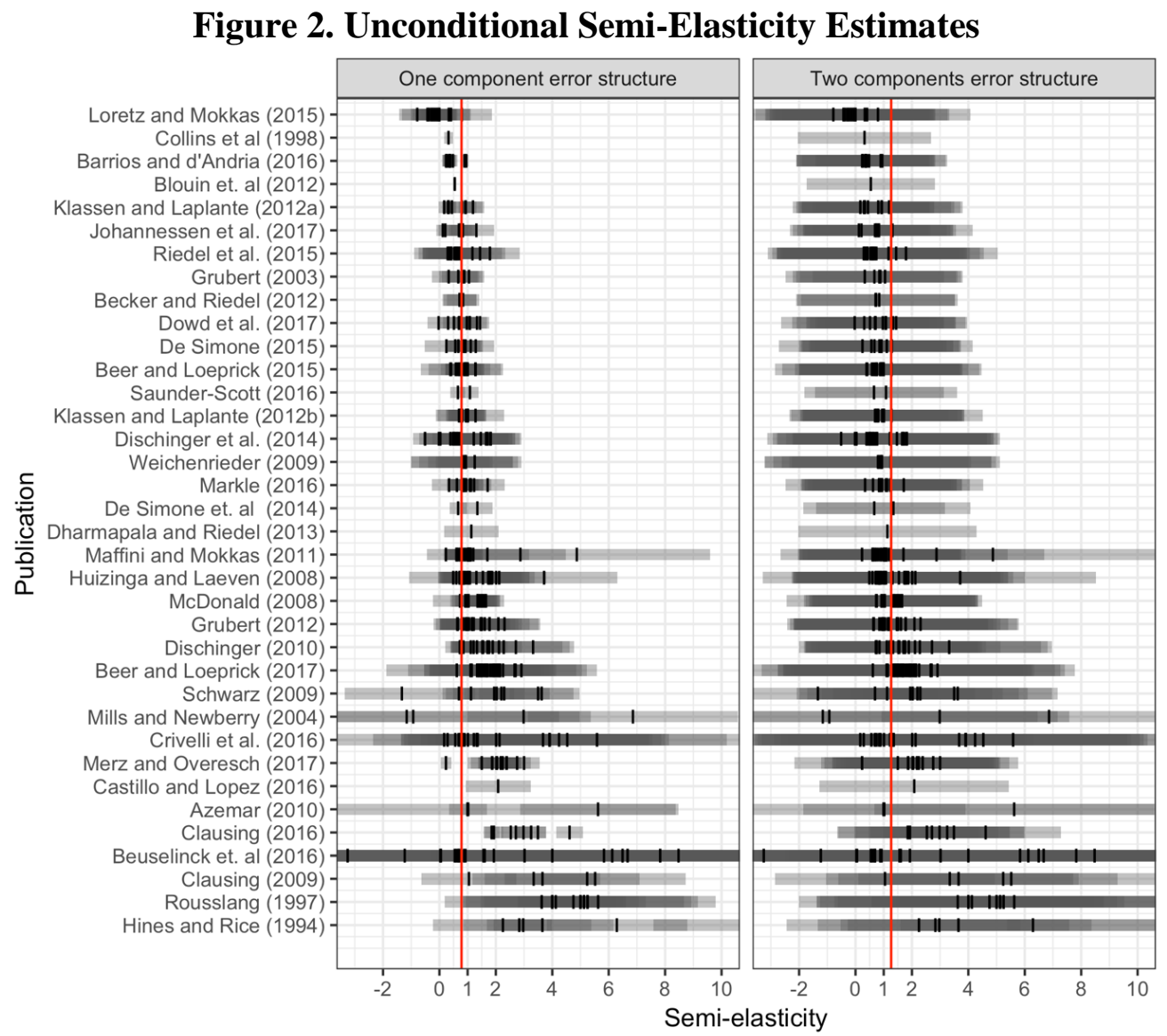

Notes: the short vertical black lines denote study means, the (overlapping) clouds indicate associated confidence bands. The long red vertical lines denote the unconditional mean of all semi-elasticity estimates in our sample using WLS (left panel) and GLS (right panel) estimation.

Figure 2 contrasts WLS (left panel) and GLS (right panel) estimates of the unconditional mean (red vertical line) in the baseline sample. Small vertical black lines depict point estimates; grey clouds around these point estimates illustrate associated 95 percent confidence bands. In the left panel, we use the standard errors which are reported in primary studies to illustrate these confidence bands, thus ignoring correlation at the study level. Many confidence intervals do not encompass the mean value in the left panel, suggesting 
that reported semi-elasticities and associated standard errors are from different distribution. ${ }^{21}$ In contrast, the right panel presents confidence bands that account for variation at the studylevel, and show considerable more overlap. ${ }^{22}$

The simple graphical evidence suggests that a two-component error structure is more suitable to describe the unconditional mean in the baseline sample. Similarly, we do find that an important share of the observed variation is at the study level in all conditional estimations of the mean (see regression results in the next section). Accordingly, we use GLS in all estimations to improve estimation precision over previous work.

\section{Main Findings}

Table 2 summarizes our regression results based on Equation (3) using the baseline sample. The dependent variable is the reported semi-elasticity of pre-tax profits, winsorized at top and bottom one percentile to remove the influence of outliers. ${ }^{23}$ We account for heteroscedasticity and intra-study correlation by presenting fully robust GLS standard errors (see e.g. Arellano, 2003 and Wooldridge, 2010). Moreover, we correct for the small number of clusters by inflating residuals ${ }^{24}$ and reporting $p$-values based on $t$-distributions with $G-1$ degrees of freedom, where $\mathrm{G}$ is the number of the included studies (see Cameron, Gelbach, and Miller, 2006).

Column 1 of Table 2 examines the joint impact of estimation techniques and data sources on measured semi-elasticities. The average semi-elasticity estimate is 0.72 , when using micro data and including firm fixed effects. The coefficient on the indicator No Firm FE is positive and significant at the one percent level, suggesting that the assumption of no correlation between unobservable components at the firm-level and the dependent variable might be violated in these models. Omitting country fixed effects increases the estimated semielasticity by an average of 0.46 .

Among studies using aggregate data, estimated semi-elasticities are significantly larger and more sensitive to the inclusion of country-specific fixed effects. The coefficient on the Aggregate Data indicator of 1.11, which is significant at the 5 percent level, suggests that the data sources differ beyond the ability to control for unobservable factors at the firm level. With a magnitude of $2.29(=0.72+0.46+1.11)$, the implied semi-elasticity for macro-studies is much larger than the effect identified in micro-studies. Two explanations seem possible. On the one hand, macro-data potentially captures long-run responses and more channels. On the

\footnotetext{
${ }^{21}$ Otherwise we would expect that around 95 percent of these confidence bands do cover the red line.

${ }^{22}$ In other words, we use equation (5) to estimate $\widehat{\sigma^{2}}$ in the right panel, where the clouds cover roughly 2 times $\sqrt{\widehat{\sigma^{2}}+\sigma_{i j}^{2}}$ in each direction. In contrast, we simply set $\widehat{\sigma^{2}}=0$ in the left panel.

${ }^{23}$ We check the sensitivity of our results to winsorization in Table 3 , and show that it has hardly any impact on the consensus semi-elasticity estimate.
}

${ }^{24}$ We use the factor $\left(\frac{G}{G-1}\right)^{0.5}$. 
other hand, the larger effect may reflect bias, as aggregate data does not allow to match production factors with profitability measures at the firm level and precludes computation of relevant tax differentials. Country-specific fixed effects play a similar role for aggregate data as do firm-specific fixed effects for micro-data. We acknowledge this difference by interacting the No Country FE indicator with the Aggregate Data indicator. Our findings suggest that estimated semi-elasticities increase by $0.76(=0.46+0.3)$ if macro-based studies do not control for country-specific fixed effects; this effect is significantly larger than the increase for micro-based studies.

Table 2. Baseline Results

\begin{tabular}{|c|c|c|c|c|}
\hline EXPLANATORY VARIABLE: & (1) & (2) & (3) & (4) \\
\hline \multirow[t]{2}{*}{ CONSTANT } & $0.724 * * *$ & $1.205 * * *$ & $1.017 * * *$ & $0.974 * * *$ \\
\hline & {$[0.127]$} & {$[0.244]$} & {$[0.286]$} & [0.128] \\
\hline \multirow[t]{2}{*}{ NO FIRM FE } & $0.121 * * *$ & -0.159 & -0.096 & $-0.211^{* * *}$ \\
\hline & {$[0.039]$} & [0.157] & [0.146] & {$[0.070]$} \\
\hline \multirow[t]{2}{*}{ NO COUNTRY FE } & $0.456 * * *$ & $0.468 * * *$ & $0.359 * * *$ & $0.472 * * *$ \\
\hline & {$[0.036]$} & {$[0.025]$} & {$[0.125]$} & {$[0.020]$} \\
\hline \multirow[t]{2}{*}{ AGGREGATE DATA } & $1.110^{* *}$ & $1.674 * *$ & $1.445 * *$ & $1.082 * *$ \\
\hline & {$[0.515]$} & {$[0.637]$} & {$[0.632]$} & {$[0.513]$} \\
\hline \multicolumn{5}{|l|}{ AGGREGATE DATA $*$ NO } \\
\hline \multirow[t]{2}{*}{ COUNTRY FE } & $0.302 * * *$ & $0.296 * * *$ & $0.448 * * *$ & $0.354 * * *$ \\
\hline & {$[0.045]$} & [0.044] & [0.147] & {$[0.043]$} \\
\hline \multirow[t]{2}{*}{ SINGLE RATE } & & -0.22 & -0.23 & \\
\hline & & [0.187] & [0.211] & \\
\hline \multirow[t]{2}{*}{ EFFECTIVE } & & -0.536 & -0.548 & \\
\hline & & [0.671] & [0.677] & \\
\hline \multirow[t]{2}{*}{ RATIO } & & $-0.341 * *$ & $-0.344 * *$ & $-0.374 * * *$ \\
\hline & & {$[0.152]$} & {$[0.142]$} & {$[0.069]$} \\
\hline \multirow[t]{2}{*}{ EBIT } & & -0.044 & -0.045 & \\
\hline & & [0.067] & [0.067] & \\
\hline \multirow[t]{2}{*}{ NO REAL CONTROLS } & & & $0.469 * * *$ & $0.454 * * *$ \\
\hline & & & [0.104] & {$[0.116]$} \\
\hline \multirow[t]{2}{*}{ DEBT } & & & 0.02 & \\
\hline & & & [0.113] & \\
\hline \multirow[t]{2}{*}{ NO MARKET } & & & 0.349 & \\
\hline & & & [0.319] & \\
\hline \multirow[t]{2}{*}{ NO TIME FE } & & & 0.116 & \\
\hline & & & [0.114] & \\
\hline \multirow[t]{2}{*}{ Z-MIDYEAR } & $0.035 * * *$ & $0.033 * * *$ & $0.036 * * *$ & $0.036 * * *$ \\
\hline & {$[0.008]$} & {$[0.008]$} & [0.009] & {$[0.008]$} \\
\hline \multicolumn{5}{|l|}{ GROUP VARIANCE/TOTAL } \\
\hline VARIANCE & 0.34 & 0.362 & 0.412 & 0.367 \\
\hline OBSERVATIONS & 402 & 402 & 402 & 402 \\
\hline
\end{tabular}

Notes: $* * *, * *$, and $*$ depict significance at the $1 \%, 5 \%$, and $10 \%$ level, respectively. Fully robust standard errors in square brackets. 
Column 2 of Table 2 adds dependent and tax variable characteristics, reporting an average semi-elasticity of 1.2. The firm fixed effect indicator is no longer significant, suggesting the additional controls subsume variations in the firm-level unobserved heterogeneity. The coefficient on Single Rate is -0.22 but not significant at conventional statistical levels. Similarly, the coefficient on the Effective indicator is negative and statistically insignificant. Studies using profitability ratios report significantly smaller semi-elasticities $(-0.34)$ than studies using the logarithm of reported profit. Surprisingly, we do not find systematic differences between studies using EBIT and studies using profit before taxation as a dependent variable. Debt-shifting thus plays, on average, a minor role in our baseline sample. We examine the importance of real production controls, leverage and other covariates in column 3. The coefficient on the indicator No Real Control is close to 0.5 and significant at the one percent, indicating an omitted variable bias in studies that neglect real responses to taxation. In contrast, debt ratios, macro-controls, and time fixed effects do not seem to matter systematically in our baseline sample.

Following HO, we drop insignificant explanatory variables in column 4 to increase the estimation precision. The estimated constant of 0.98 is our preferred consensus semielasticity estimate. Studies yield smaller effects if they employ a profit ratio (instead of logarithm) or use a simple statutory tax rate (instead of a differential); they yield larger estimates if they do not control for unobservable country-specific effects, real activity, or use aggregate data.

Throughout all columns the coefficient for the Z-Midyear variable is around 0.03 and significant at the one percent level, suggesting that the consensus semi-elasticity estimate increases with the sample year. For example, the consensus semi-elasticity is estimated to be 0.60 in 1990 and 1.5 in 2015. The positive coefficient of the sample year also suggests that the declining trend in the primary elasticity estimates in Figure 1 is driven by important characteristics of the primary studies other than time per se.

\section{Robustness checks}

Table 3 checks the robustness of our findings by re-estimating specification in Table 2 Column 3 with alternative samples. Column 1 examines the effect of outliers by using reported observations without winsorizing. Column 2 drops the top and bottom 5 percent of primary estimates. The results change slightly: with average values of 1.03 and 1 for the consensus estimate, respectively. 
Table 3. Robustness Checks

\begin{tabular}{|c|c|c|c|c|}
\hline $\begin{array}{l}\text { DEPENDENT VARIABLE: SEl } \\
\text { EXPLANATORY VARIABLE: }\end{array}$ & $\begin{array}{l}\text { ASTICITY } \\
\text { (1) }\end{array}$ & $\begin{array}{l}\text { PORTED } \\
(2)\end{array}$ & $\begin{array}{l}\text { (NO WINS } \\
\text { (3) }\end{array}$ & NG) \\
\hline CONSTANT & $1.026 * * *$ & $0.995 * * *$ & $1.250 * * *$ & $1.012 * * *$ \\
\hline & {$[0.292]$} & {$[0.282]$} & {$[0.256]$} & {$[0.288]$} \\
\hline NO FIRM FE & -0.102 & -0.103 & 0.595 & 0.273 \\
\hline & {$[0.146]$} & [0.143] & [0.486] & [0.630] \\
\hline NO COUNTRY FE & $0.361 * * *$ & $0.360 * * *$ & $-0.906 *$ & 0.298 \\
\hline & {$[0.124]$} & {$[0.124]$} & [0.479] & [0.684] \\
\hline AGGREGATE DATA & $1.458 * *$ & $1.461 * *$ & $1.237 *$ & 0.931 \\
\hline & {$[0.638]$} & {$[0.611]$} & [0.699] & {$[0.758]$} \\
\hline SINGLE RATE & -0.231 & -0.229 & 0.051 & -0.434 \\
\hline & {$[0.214]$} & {$[0.212]$} & [0.198] & {$[0.353]$} \\
\hline EFFECTIVE & -0.549 & -0.558 & -0.569 & $0.657 * * *$ \\
\hline & [0.679] & {$[0.678]$} & [0.694] & {$[0.163]$} \\
\hline RATIO & $-0.350 * *$ & $-0.322 * *$ & $-1.161 * *$ & -0.093 \\
\hline & {$[0.145]$} & [0.139] & {$[0.453]$} & [0.469] \\
\hline EBIT & -0.047 & 0.007 & $-0.387 *$ & $-0.282 * * *$ \\
\hline & {$[0.068]$} & {$[0.020]$} & {$[0.206]$} & [0.102] \\
\hline NO REAL CONTROL & $0.475 * * *$ & $0.426^{* * *}$ & $0.810 * * *$ & $0.734 * * *$ \\
\hline & [0.108] & {$[0.084]$} & {$[0.160]$} & {$[0.145]$} \\
\hline DEBT & 0.022 & 0.032 & -0.081 & $-0.248 * *$ \\
\hline & {$[0.114]$} & {$[0.124]$} & {$[0.154]$} & {$[0.114]$} \\
\hline NO MARKET & 0.348 & 0.356 & $1.034 * * *$ & -0.105 \\
\hline & {$[0.322]$} & {$[0.317]$} & [0.353] & [0.078] \\
\hline NO TIME FE & 0.115 & 0.116 & -0.169 & -0.037 \\
\hline & [0.114] & [0.114] & [0.160] & {$[0.224]$} \\
\hline AGGREGATE DATA * NO & & & & \\
\hline COUNTRY FE & $0.447 * * *$ & $0.440 * * *$ & $1.060 * *$ & NA \\
\hline & {$[0.146]$} & {$[0.145]$} & {$[0.478]$} & NA \\
\hline Z-MIDYEAR & $0.036 * * *$ & $0.036^{* * *}$ & $0.029 * * *$ & $0.069 * *$ \\
\hline & [0.009] & [0.009] & [0.003] & {$[0.031]$} \\
\hline GROUP VARIANCE/TOTAL & & & & \\
\hline VARIANCE & 0.336 & 0.801 & 0.291 & 0.704 \\
\hline OBSERVATIONS & 402 & 380 & 328 & 208 \\
\hline
\end{tabular}

Notes: $* * *, * *$, and $*$ depict significance at the $1 \%, 5 \%$, and $10 \%$ level, respectively. Fully robust standard errors in square brackets.

Column 3 excludes studies that are not published in peer-reviewed journals, and reports a slightly larger consensus estimate of 1.25 . While most indicator variables have the expected signs, two differences emerge: first, the omission of country-specific fixed effects now impacts negatively on measured semi-elasticities. Second, we find a negative and significant coefficient on the indicator EBIT. Profit before interest and taxation decreases, on average, by $0.86(=1.25-0.39)$ percent in response to a one percentage point increase in the local statutory tax rate. The two estimates on the semi-elasticity of profits, before and after 
financial income, allow gauging the importance of debt shifting relative to other channels of profit shifting. Assuming that interest payment account for 9 percent of pre-tax profit, ${ }^{25}$ if MNCs neglect financial channels to shift profit, the measured semi-elasticity of profit after interest payments should be 9 percent larger than the semi-elasticity of profit before interest payments. ${ }^{26} \mathrm{We}$ would thus expect to find a semi-elasticity of 0.94 when using profit after interest payments. However, the measured semi-elasticity for profit after interest is 1.25 , indicating that MNCs also use financial channels to manipulate profit. Comparing these effects implies that financial tax avoidance strategies account for roughly one quarter $(=(1.25-0.94) / 1.25)$ of the total profit shifting response.

\section{Publication Bias}

In principle, estimated semi-elasticities and reported standard errors should be independently distributed. However, researchers, editors, and referees tend to prefer significant statistical results over insignificant results and previous work has indicated that selective reporting and publication of empirical findings is ubiquitous in the economics literature (see e.g. Card and Krueger, 1995; Ashenfelter, 1999; Doucouliagos and Stanely, 2013). Empirical work on profit shifting is likely no exception.

Theoretical considerations imply that profit shifting induces a negative correlation between reported profit and the tax differential. However, data sources often have insufficient detail and local statutory tax rates change infrequently. As a result, the identified effect is sometimes imprecisely measured and random errors might even lead to estimated semielasticities which are positive. If researchers do not report such estimates, our metaregression suffers from sample selection and the mean estimate will be upward biased. Besides selective reporting, researchers potentially re-estimate the same regression with slight perturbations ( $p$-hacking) to provide statistically significant results. While this practice does not necessarily introduce bias in reported semi-elasticities, it does induce a correlation between standard errors and coefficient estimates, which impacts estimations using reported standard errors as weights.

Figure 3 presents two pieces of graphical evidence to explore the potential of publication bias in our sample. The left panel presents a funnel plot, where the inverse of reported standard errors is plotted against the reported semi-elasticity. Observations located at the top of the graph are accurately measured and should thus approximate the true mean. In contrast, observations at the bottom of the graph are imprecisely measured and on average expected to deviate to a larger degree from the mean. The plot clearly conveys asymmetry in the distribution of reported estimates, suggesting that the probability of ending up in our sample decreases substantially if the semi-elasticity carries the wrong sign. The right panel presents the density of $t$-values in our sample, where the vertical line depicts the critical value of 1.96. The spike right next to this line is consistent with $p$-hacking.

\footnotetext{
${ }^{25}$ For instance, the average ratio of pre-tax EBIT to profit, based on consolidated financial statements for the largest 1,000 non-financial companies (measured by total assets) in ORBIS is 1.09 in 2011.

${ }^{26}$ Note that $\mathrm{d}[\mathrm{f}(\mathrm{t})(1+\mathrm{r})] / \mathrm{dt}=(1+\mathrm{r}) \mathrm{f}^{\prime}(\mathrm{t})$, where $r$ is the constant interest rate.
} 
Figure 3. Graphical Evidence for Publication Bias
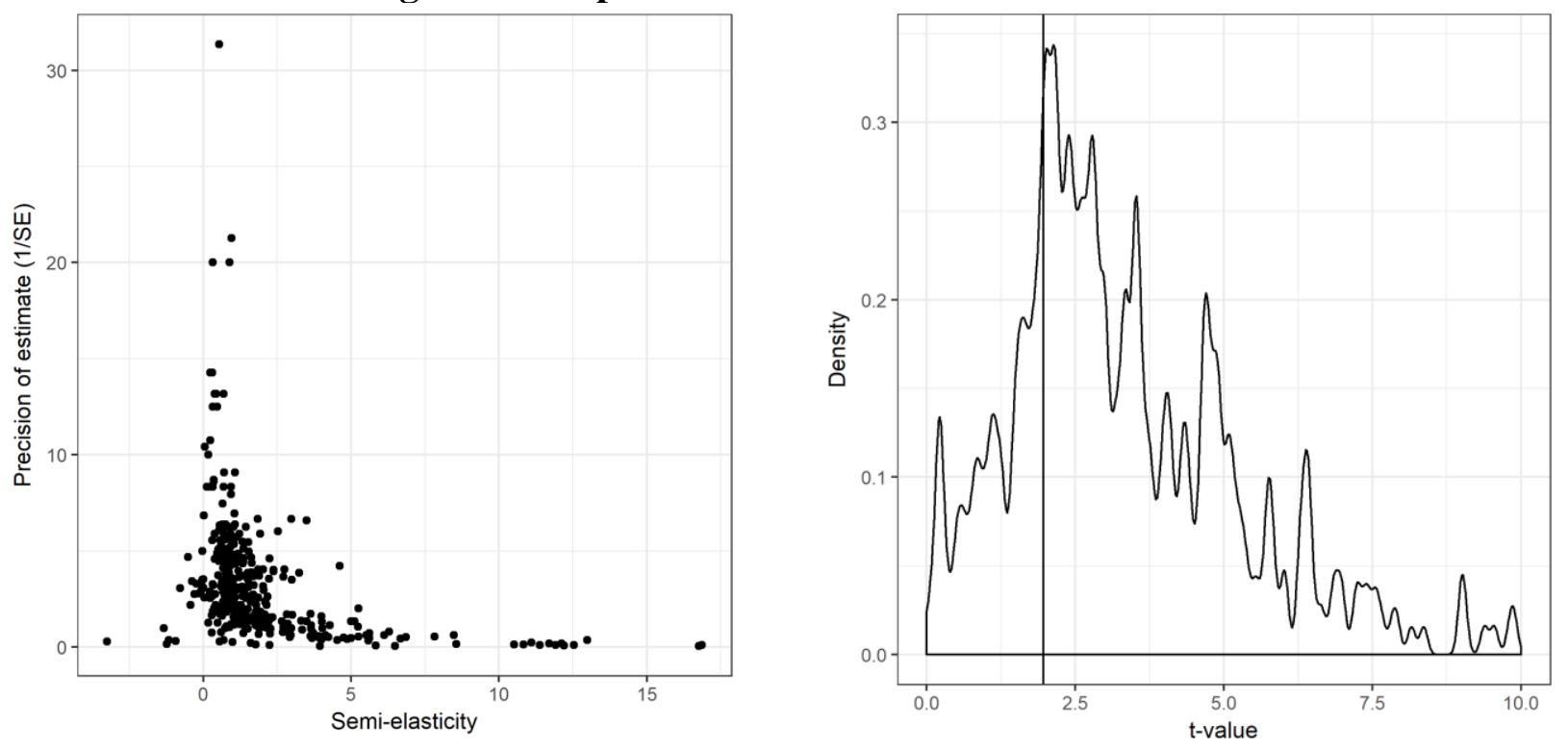

Notes: Left panel plots semi-elasticities against standard errors. Points above the line in the left panel are significant at the 5\% level. Right panel plots the density of associated t-values (semi-elasticity/standard error). The vertical line in the right panel depicts a t-value of 1.96 .

Table 4. Evidence on Publication Bias

\begin{tabular}{|c|c|c|c|}
\hline \multicolumn{4}{|c|}{ Dependent variable: semi-elasticity estimates (no winsorizing) } \\
\hline & (1) & $(2)$ & $(3)$ \\
\hline \multirow[t]{2}{*}{ Constant } & $0.520^{* * *}$ & $0.509 * *$ & $0.548 * *$ \\
\hline & {$[0.219]$} & {$[0.239]$} & {$[0.240]$} \\
\hline \multirow[t]{2}{*}{ SE } & $1.986^{* * *}$ & $2.033 * * *$ & $1.901 * * *$ \\
\hline & [0.385] & [0.432] & [0.404] \\
\hline SE*zMidyear & & 0.044 & \\
\hline & & {$[0.050]$} & \\
\hline SE*WP & & & 1.011 \\
\hline & & & [0.696] \\
\hline Controls & Yes & Yes & Yes \\
\hline $\begin{array}{l}\text { Group Variance/ Total } \\
\text { variance }\end{array}$ & 0.31 & 0.317 & 0.321 \\
\hline Observations & 402 & 402 & 402 \\
\hline
\end{tabular}

Notes: $* * *, * *$, and $*$ depict significance at the $1 \%, 5 \%$, and $10 \%$ level, respectively. Fully robust standard errors in square brackets.

Table 4 column 1 examines the presence of publication bias by estimating the baseline specification, adding the reported standard error as an additional explanatory variable. ${ }^{27}$ The positive effect of the standard errors on reported semi-elasticities is significant at the one percent level and consistent with publication bias. The implied publication bias is not related

${ }^{27}$ For brevity, we omit the estimated coefficients on other control variables. 
to the average sample year (column 2) or whether an estimate was taken from a published study or from an unpublished study (column 3).

\section{E. Simulation of Revenue Effects}

This section illustrates the revenue impact of profit shifting using the consensus estimate. ${ }^{28}$ Specifically, drawing on the theoretical model of Huizinga and Laeven (2008), which we elaborate in Appendix 3, the observed tax base in country $i\left(\pi_{i}\right)$ is the sum of true profits $\left(B_{i}\right)$ and shifted income $S_{i}$ :

$$
\pi_{i}=B_{i}+S_{i}(\boldsymbol{B}, \varepsilon, \boldsymbol{\tau}), \quad \text { for all } i=1, \ldots N
$$

Shifted income can be either positive or negative and is a function of the unobservable vector of true earnings before profit shifting $(\boldsymbol{B})$, where different elements of $\boldsymbol{B}$ refer to true earnings in different countries that the MNC operates, the semi-elasticity of reported earnings $(\varepsilon$, negative) and the vector of tax rates in countries where the MNC operates (based on profit maximization set out in equation A. 1 in Appendix 3):

$$
S_{i}=\left(\frac{B_{i}}{\varepsilon}\right) \frac{\sum_{k \neq i}^{n}\left(\frac{B_{k}}{1-\tau_{k}}\right)\left(\tau_{k}-\tau_{i}\right)}{\sum_{k=1}^{n}\left(\frac{B_{k}}{1-\tau_{k}}\right)}
$$

For a given semi-elasticity, vector of tax rates, and observed tax bases, the true tax base vector $\boldsymbol{B}=f(\boldsymbol{\pi}, \varepsilon, \boldsymbol{\tau})$ can be imputed from Equation (6) with the expression for $S_{i}$ above.

For the calculations, we obtain corporate tax rates for 2015 in 81 countries from the KPMG database. We obtain corporate tax bases of these countries by dividing corporate tax revenues for 2015, obtained from the IMF's government finance statistics, by statutory tax rates. ${ }^{29} \mathrm{We}$ then calculate for each country the tax base without profit shifting, the amount of profits shifted in or out of the country, and the associated revenue effect. In the calculations, we impute the semi-elasticity to be 1.5 for the year 2015 , using the preferred semi-elasticity of 0.98 (Table 2, column 4) and the Z-Midyear coefficient of 0.036 .

\footnotetext{
28 These calculations should be interpreted with caution, since they are based on a highly stylized model and do not account for heterogeneity across countries and firms. Thus, it is meant only as an illustration of what the average semi-elasticity obtained in the previous subsection means in terms of the allocation of tax bases and, consequently, corporate tax revenue.
}

\footnotetext{
${ }^{29}$ Note that this approach introduces two counterbalancing inaccuracies: first, by using total corporate revenues rather than the share of revenues from MNCs, we may overestimate the relevant tax base. Second, by ignoring the effect of accelerated depreciation, tax losses, and other provisions in determining the actual tax liability of corporations the statutory tax rate can be much higher than the effective average tax rate. By dividing total revenue by statutory rates, we thus underestimate the relevant tax base.
} 
Table 5 summarizes the simulation results for four country groups: the US, the 15 largest countries in the sample, the 15 countries with the lowest corporate tax rates, and the average among all 81 countries. Column (1) of Table 5 suggests that reported corporate tax revenue in the US is roughly US\$ 360 billion in 2015 . The combined federal and state tax rate of 40 percent implies an underlying reported tax base of US\$900 billion. The high statutory corporate tax rate relative to the rest of the world implies a net outward profit shifting from the US of US\$ 198 billion, implying a true tax base of roughly US \$1,095 billion. Hence, profit shifting activities eroded the US tax base by about 17 percent, or 0.4 percent of US GDP. ${ }^{30}$ This number is comparable to the 14.4 percent reported by Zucman (2014), but somewhat smaller than Clausing (2016) who estimates a revenue loss between 19 and 30 percent of corporate tax revenue, and Torslov et al (2018) who estimate it at 40 percent of tax revenue from MNCs.

Table 5. Estimated Revenue Losses

\begin{tabular}{lcrrr}
\hline \multicolumn{1}{c}{ Country } & US & Big 15 & Low-tax 15 & Global \\
& \multicolumn{1}{c}{$(1)$} & $(2)$ & $(3)$ & \multicolumn{1}{c}{$(4)$} \\
\hline CIT revenue (in billion. US\$) & 363 & 1,563 & 49 & 1,888 \\
CIT rate (federal + state, \%) & 40 & 31 & 15 & 30 \\
Reported CIT base & 907 & 4,983 & 318 & 6,213 \\
True CIT base & 1,095 & 5,0784 & 263 & 6,213 \\
Corporate income shifted & 198 & 102 & -55 & 0 \\
Revenue loss (in \% of CIT revenue) & 17.2 & 4.1 & -19.8 & 2.6 \\
Revenue loss (in \% of GDP) & 0.42 & 0.11 & -0.43 & 0.07 \\
\hline Note: we calculate the variables as follows: CIT revenue is $\sum_{i} \tau \pi_{i}$, reported CIT base is $\sum_{i} \pi_{i}$, pre-shifting \\
CIT base is $\sum_{i} B_{i}$, Income shifted is $\sum_{i} S_{i}$, tax revenue losses is $\frac{\sum_{i} \tau_{i} S_{i}}{\sum_{i} \tau_{i} B_{i}}$ and revenues.
\end{tabular}

Columns 2 and 3 present the average effect for the largest 15 economies (Big 15), including the US, and the 15 countries with the lowest statutory tax rate (Low-tax 15). Compared to the US, the revenue consequences of profit shifting are much smaller for Big 15: corporate tax revenue declines in these countries by an average 4 percent, or by 0.11 percent of GDP. The reason is that several large countries have CIT rates below the world average. As a result, the 15 countries with the lowest statutory CIT rate gain from inward profit shifting, with corporate tax revenues increasing by almost 20 percent, or by 0.43 percent of their GDP.

Column 4 further shows the global net revenue effect of profit shifting, i.e. the balance of the gains in some countries and the losses in other countries. While the total of shifted income is equal to zero (by definition, as cross-border profit shifting does not change the total income of a MNC), the shifting from high-tax to low-tax countries reduces the total of corporate tax revenue by 2.6 percent of corporate tax revenues, or 0.07 percent of global GDP. These numbers are somewhat smaller than those reported by Crivelli et al. (2017), OECD (2015), and UNCTAD (2015).

\footnotetext{
${ }^{30}$ Following the US Tax Cuts and Jobs Act (TCJA), global profit shifting patterns are likely to change substantially (see, e.g. Beer et al 2018).
} 
Figure 4 presents country-specific results for a selection of simulated variables. The graph shows that seven large economies actually gain from profit shifting because their rate is lower than those prevailing elsewhere.

sFigure 4. Country-Specific Estimates of Fiscal Impact

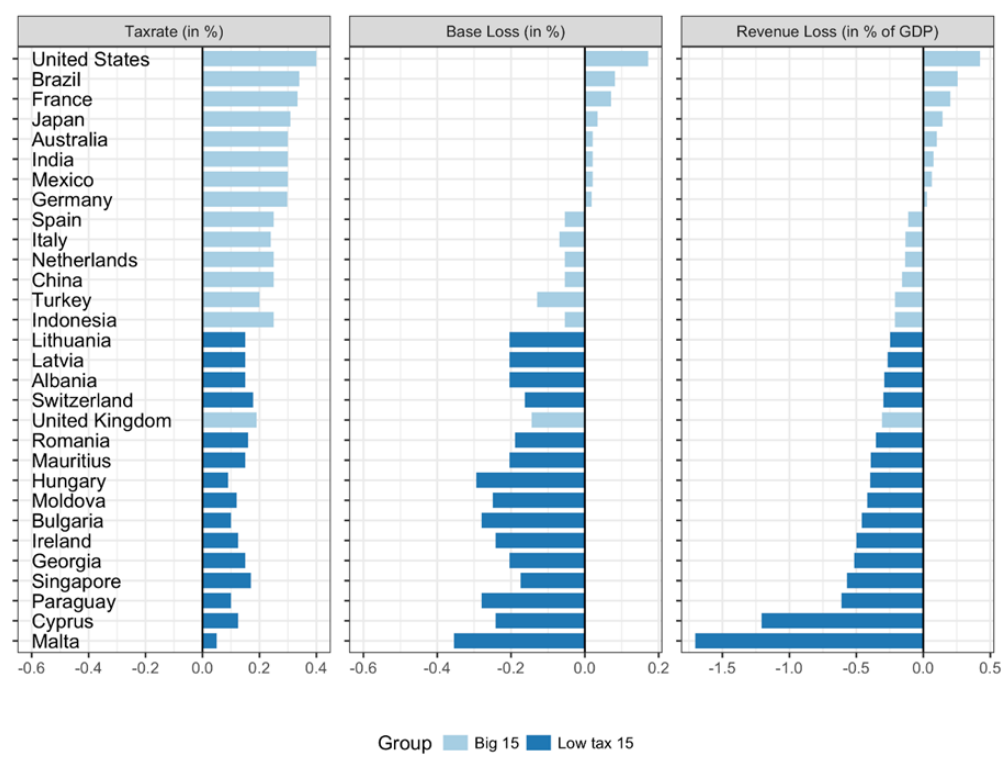

Notes: Figure 4 illustrates simulation results, depicting tax rates (left panel), changes in the tax base due to profit shifting (middle panel), and revenue losses due to profit shifting (right panel). Negative base and revenue losses are gains.

\section{Discussions AND CONCLUSION}

The existing literature on international tax avoidance has significantly advanced over recent years, but there remain several blind spots and puzzles that future research should address.

First, we reviewed granular evidence on tax-motivated behavioral responses of MNCs in areas such as transfer mispricing, strategic location of intangibles, intra-company debt shifting, treaty shopping, corporate inversion, and tax deferral. However, there is much less evidence on some of the other channels of profit shifting. For example, MNCs can structure their businesses to artificially avoid the creation of permanent establishments, thus escaping source country taxation at the outset. Alternatively, they can exploit mismatches in national tax rules, when different countries classify the same entity, transaction, or financial instrument differently. ${ }^{31}$ Another pressing issue for especially developing countries relates to the taxation of offshore indirect transfers of assets, where MNCs avoid taxes on significant capital gains in source countries (see, e.g. Wei (2015) and IMF (2018)). Understandably, the lack of systematic analysis on these alternative channels of profit shifting is due to both their highly technical and complex nature and the lack of suitable data. More and deeper analysis

\footnotetext{
${ }^{31}$ A notable exception is Hardeck and Wittenstein (2017), which use the Luxembourg Leaks database and show that hybrid arrangements by MNCs are related to substantial and continuous reduction in the effective tax rate of MNCs. The empirical evidence provide support for the considerable tax benefits of hybrid arrangements outline in theoretical research by Johannesen (2014).
} 
in this area is needed to advance our understanding on the anatomy of international tax avoidance.

Second, there is little evidence on the interaction between alternative modes of profit shifting. Empirical work tends to focus on specific channels in isolation, so it is difficult to infer information about substitution between alternative channels. A notable exception is Saunders-Scott (2016), who provides insight into whether transfer mispricing and debt shifting are substitutes or complements. The study examines changes in the reported EBIT following a tightening of thin-capitalization rules for multinational affiliates, using the ORBIS database. The findings suggest that MNCs use transfer mispricing and intra-company debt shifting as substitutes (see also Nicolay et.al. (2017)). More research is needed in this direction in order to shed light on how successful targeted anti-abuse rules are in restricting the overall extent of international tax avoidance by MNCs.

Third, there is limited insight into the systematic variation in tax avoidance across countries, sectors, firms and time. Indeed, the relative costs of various shifting methods are likely to differ in all these dimensions. Therefore, conclusions of certain studies are hard to generalize to all MNCs or all countries. Recently, some studies have started to focus on specific sectors or extended the scope to developing countries. For example, using tax records of US MNCs, Dowd et al (2017) find significant non-linear effect of tax differential that points to more shifting into tax havens. Findings by Johannessen, Torslov, and Wier (2017), which uses data from multinational affiliates in 142 countries, including 25,000 corporations in 94 developing countries (from ORBIS), suggest that less developed countries are more exposed to crossborder profit shifting. ${ }^{32}$ The literature is too scattered, however, to draw firm conclusions on important sources of heterogeneity.

Fourth, there is little attention in the literature on the interaction between profit shifting and the reallocation of real activities by MNCs. Existing research has focused largely on quantifying either the scale of profit shifting or the impact of taxes on the location of FDI. Yet, profit shifting may interact with investment and thus have complex and unexpected welfare implications, with important policy implications. For instance, some have argued that profit shifting can mitigate distortions from existing tax systems on real capital (Hong and Smart, 2010; Desai, Foley and Hines, 2006). Anti-avoidance measures might then reduce welfare to the extent that they magnify distortions in real capital allocation.

Only a handful of recent studies analyze the spillover effect of anti-avoidance rules on investment. For example, De Mooij and Liu (2018) exploit introductions and tightening of transfer pricing regulation in countries as a quasi-natural experiment and find that transfer pricing regulation has a negative and significant effect on MNC investment in fixed assets. Buettner et al. (2017) provide evidence that thin-capitalization rules have a negative effect on MNC investment financed by debt. Egger and Wamser (2015) explore whether limitations to

\footnotetext{
${ }^{32}$ On the extensive margin, Johannessen, Torslov, and Wier (2017) reports that the tax rate faced by a foreign affiliate has a significant positive effect on the likelihood that the affiliate reports zero profits. On the intensive margin, the tax semi-elasticity of reported profits is found to be around 1 in low/middle-income countries, but less than 0.2 in high-income countries.
} 
foreign income exemptions affect investment using a regression continuity design. They find that the German CFC rule decreased foreign subsidiaries' real investments. The scarce evidence thus suggests that unilateral tightening of profit shifting through anti-avoidance rules may have negative effects on MNC investment. More evidence is needed, however, to inform the debate on effective policy design, including through international coordination.

There are also several puzzles in the literature that remain partially unresolved. One is the 'large aggregate effects' versus 'small micro effects'. In particular, our meta regressions suggest that firm-responses reflected in aggregated data are substantially larger than in micro data, thereby controlling for several study attributes that may confound the estimated semielasticities in primary studies. Our interpretation of this difference is between short-term and long-term responses, e.g. due to adjustment costs and optimization frictions (i.e. fixed costs of tax planning). Indeed, micro-studies typically exploit variation across time from which the contemporaneous effect is obtained while macro-studies exploit cross-sectional variation that yield an estimate of the long-run effect. Moreover, macro studies may cover a wider array of shifting channels than micro studies. Whether this is indeed the case should be explored more deeply.

Another puzzle is our finding regarding debt shifting. The literature directly exploring the extent of debt shifting finds a robust significant impact of corporate tax differences on intracompany debt. One would expect that this would be reflected in studies on the total size of profit shifting by showing a systematic difference between studies using profit indicators that include and exclude interest costs. While our meta regressions confirm this difference, deeper analysis is needed to explain this, which might include methodological issues such as omitted variable bias or attenuation bias. 


\section{References}

Altshuler, R. and T.S. Newlon. 1993. The Effects of US Tax Policy on the Income Repatriation Patterns of US Multinational Corporations, in A. Giovannini, R.G. Hubbard and J. Slemrod eds. Studies in International Taxation, Chicago: University of Chicago Press, 77-115.

, T.S. Newlon and W.C. Randolph. 1995. Do Repatriation Taxes Matter? Evidence from the Tax Returns of US Multinationals, in M. Feldstein, J.R. Hines and R.G. Hubbard eds The Effects of Taxation on Multinational Corporations, Chicago: University of Chicago Press, 253-272.

and Harry Grubert. 2003. Repatriation Taxes, Repatriation Strategies and Multinational Financial Policy, Journal of Public Economics, 87, issue 1, p. 73-107.

Arellano, M. 2003. Panel Data Econometrics, Advanced Texts in Econometrics, Oxford University Press.

Ashenfelter, Orley, Colm Harmon, and Hessel Oosterbeek, 1999. A Review of Estimates of the Schooling/Earnings Relationship, with Tests for Publication Bias, Labour Economics 6, pp. 453-47.

Azémar, C. 2010, International Corporate Taxation and U.S. Multinationals' Behaviour: An Integrated Approach. Canadian Journal of Economics, 43: 232-253.

Balabushko, Oleksii, Sebastian Beer, Jan Loeprick and Vallada, Felipe Pinto. 2017. The Direct and Indirect Costs of Tax Treaty Policy: Evidence from Ukraine, World Bank Policy Research Working Paper No. 7982.

Barrios, Salvador, Harry Huizinga, Luc Laeven, Gaëtan Nicodème. 2012. International Taxation and Multinational Firm Location Decisions, Journal of Public Economics, Volume 96, Issues 11-12, 2012, Pages 946-958.

Becker, Johannes and Nadine Riedel. 2012. Cross-Border Tax Effects on Affiliate Investment-Evidence from European Multinationals, European Economic Review, 56, issue 3, p. 436-450.

Beer, Sebastian, Alexander Klemm, and Thornton Matheson. 2018. Tax Spillovers from U.S. Corporate Income Tax Reform. forthcoming IMF Working Paper. and Jan Loeprick. 2015. Profit shifting: Drivers of Transfer (mis)pricing and the Potential of Countermeasures, International Tax and Public Finance, 22, issue 3, p. 426-451. 
and Jan Loeprick. 2017. Taxing Income in the Oil and Gas Sector - Challenges of International and Domestic Profit Shifting, Energy Economics, 61, issue C, p. 186198.

and Jan Loeprick. 2018. The Costs and Benefits of Tax Treaties with Investment Hubs: Findings from Sub-Saharan Africa. forthcoming IMF Working Paper.

Bernard, Andrew B., J. Bradford Jensen, and Peter K. Schott. 2006. "Transfer Pricing by U.S.-Based Multinational Firms," Working Paper 12493, National Bureau of Economic Research. August.

Beuselinck, C., M. Deloof, and A. Vanstraelen. 2015. Cross-Jurisdictional Income Shifting and Tax Enforcement: Evidence from Public versus Private Multinationals, Review of Accounting Studies, vol. 20 no. 2, pp. 710-746.

Blouin, J. L., L.A. Robinson, and J.K. Seidman. 2018. Conflicting Transfer Pricing Incentives and the Role of Coordination. Contemporary Accounting Research, 35: 87116.

, Harry Huizinga, Luc Laeven, and Gaëtan Nicodème. 2014. "Thin Capitalization Rules and Multinational Firm Capital Structure," CESifo Working Paper Series 4695, CESifo Group Munich

Buettner, Thiess, Michael Overesch, and Georg Wamser. 2017. Anti-Profit-Shifting Rules and Foreign Direct Investment, International Tax and Public Finance, forthcoming. and Georg Wamser. 2013. Internal Debt and Multinational Profit Shifting: Empirical Evidence from Firm-Level Panel Data, National Tax Journal, National Tax Association, vol. 66(1), pages 63-95, March.

and Michael Overesch, Ulrich Schreiber, and Georg Wamser. 2012."The Impact of Thin-Capitalization Rules on the Capital Structure of Multinational Firms," Journal of Public Economics, Elsevier, vol. 96(11), pages 930-938.

Boskin, M.J. and W.G. Gale. 1987. "New Results on the Effects of Tax Policy on the International Location of Investment" in M. Feldstein ed. The Effects of Taxation on Capital Accumulation, Chicago: University of Chicago Press.

Cameron, Colin, Jonah Gelbach, and Douglas Miller. 2008. Bootstrap-Based Improvements for Inference with Clustered Errors. The Review of Economics and Statistics. Vol 90(3) pp. 414-427

Card, David and Alan B. Krueger. 1995. Time-Series Minimum-Wage Studies: A MetaAnalysis. The American Economic Review. Vol. 85, No. 2. pp. 238-243 
Castillo Murciego, Ángela and Julio López Laborda. 2016. Are Spanish Companies involved in Profit Shifting? Consequences in Terms of Tax revenues. Economics Discussion Papers, No. 2016-28

CBO. 2017. An Analysis of Corporate Inversions, Congressional Budget Office Report, Washington DC.

Clausing, K. A. 2001. Trade Creation and Trade Diversion in the Canada - United States Free Trade Agreement. Canadian Journal of Economics, 34: 677-696. 2003. Tax-Motivated Transfer Pricing and US Intrafirm Trade Prices, Journal of Public Economics, vol. 87(9-10), pages 2207-2223. . 2006. International Tax Avoidance and U.S. International Trade, National Tax Journal, 59(2): 269-287.

. 2009. Multinational Firm Tax Avoidance and Tax Policy. National Tax Journal, 62(4), 703-725.

2016. The Effect of Profit Shifting on the Corporate Tax Base in the United States and Beyond, National Tax Journal, 69(4), pages 905-934.

Clifford, Sarah. 2017. Taxing Multinationals Beyond Borders: Financial and Locational Responses to CFC Rules, EPRU Working Paper Series, 2017-02.

Collins, J., D. Kemsley, and M. Lang. 1998. Cross-Jurisdictional Income Shifting and Earnings Valuation. Journal of Accounting Research, 36(2), 209-229.

Crivelli, Ernesto, Ruud de Mooij, and Michael Keen. 2016, Base Erosion, Profit Shifting and Developing Countries, FinanzArchiv: Public Finance Analysis, 72, issue 3, p. 268301

Cristea, Anca and Daniel Nguyen. "Transfer Pricing by Multinational Firms: New Evidence from Foreign Firm Ownerships," American Economic Journal: Economic Policy, 2016, 8 (3), 170-202.

Cui, Wei. 2015, Taxation of Non-residents' Capital Gains, in Hugh Alt and Brian Arnold (eds) United Nations Handbook on Selected Issues in Portecting the Tax Base of Developing Countries, pp. 107-154 (United Nations).

Davies, Ronald B., Julien Martin, Mathieu Parenti, and Farid Toubal. "Knocking on Tax Haven's Door: Multinational Firms and Transfer Pricing," Review of Economics and Statistics, forthcoming.

De Mooij, Ruud and Sjef Ederveen. 2008. Corporate tax elasticities: a reader's guide to empirical findings, Oxford Review of Economic Policy, 24, issue 4, p. 680-697. 
2011. The Tax Elasticity of Debt: A Synthesis of Size and Variation, IMF Working Paper 11/95.

and Li Liu. 2018. At a Cost: the Real Effects of Transfer Pricing Regulations, IMF Working Paper 18/69.

Dharmapala, D. 2014. What Do We Know about Base Erosion and Profit Shifting? A Review of the Empirical Literature. Fiscal Studies, 35: 421-448.

and Nadine Riedel. 2013. Earnings shocks and tax-motivated income-shifting: Evidence from European multinationals, Journal of Public Economics, 97, issue C, p. 95-107.

Desai, M. A., C. F. Foley, and J. R. Hines Jr., 2006. The Demand for Tax Haven Operations, Journal of Public Economics, 90(3), 513-531.

, C. F. Foley and J. R. Hines Jr., 2007. Dividend Policy Inside the Multinational Firm. Financial Management 36, 1: 5-26.

and J. R. Hines, Jr., 2002. Expectations and Expatriations: Tracing the Causes And Consequences Of Corporate Inversions, National Tax Journal, v55, 409-440.

Devereux, Michael P. 2007. The Impact of Taxation on the Location of Capital, Firms and Profit: A Survey of Empirical Evidence, Working Papers 0702, Oxford University Centre for Business Taxation.

De Simone, Lisa, Kenneth J. Klassen, and Jeri K. Seidman. 2017. Unprofitable Affiliates and Income Shifting Behavior. The Accounting Review. Volume 92 (3). pages 113136.

2016. Does a Common Set of Accounting Standards affect Tax-Motivated Income Shifting for Multinational Firms? Journal of Accounting and Economics, Volume 61, Issue 1, Pages 145-165.

and Nadine Riedel. 2011. Corporate Taxes and the Location of Intangible Assets within Multinational Firms, Journal of Public Economics, Volume 95, Issues 7-8, Pages 691-707.

, Bodo Knoll, and Nadine Riedel. 2014. The Role of Headquarters in Multinational Profit Shifting Strategies, International Tax and Public Finance, 21, issue 2, p. 248271.

Dowd, Tim, Paul Landefeld, and Anne Moore. 2017. Profit Shifting of U.S. Multinationals, Journal of Public Economics, Volume 148, 2017, Pages 1-13, ISSN 0047-2727. 
Doucouliagos, C and Stanely, 2013. Are all Economic Facts Greatly Exaggerated? Theory Competition and Selectivity. Journal of Economic Surveys 27(2), pp. 316-399.

Dudar, Olena and Johannes Voget. 2016. Corporate Taxation and Location of Intangible Assets: Patents vs. Trademarks, No 16-015, ZEW Discussion Papers, ZEW - Center for European Economic Research.

Egger, Peter, Valeria Merlo, Martin Ruf, and Georg Wamser. 2015. "Consequences of the New UK Tax Exemption System: Evidence from Micro-Level Data," Economic Journal, vol. 125(589), pages 1764-1789.

Feld, Lars P., Jost H. Heckemeyer and Michael Overesch. 2013. Capital Structure Choice and Company Taxation: A Meta-Study, Journal of Banking \& Finance, Volume 37, Issue 8, Pages 2850-2866.

Flaaen, Aaron. 2016. "The Role of Transfer Prices in Profit-Shifting by U.S. Multinational Firms: Evidence from the 2004 Homeland Investment Act," mimeo, Federal Reserve Board. 2016.

Fuest, Clemens, Shafik Hebous and Nadine Riedel. 2011. International Debt Shifting and Multinational Firms in Developing Economies, Economics Letters, Volume 113, Issue 2, Pages 135-138.

Gravelle, Jane. 2015 Tax Havens: International Tax Avoidance and Evasion. Congressional Research Service Report. 7-5700.

Griffith, Rachel, Helen Miller, and Martin O'Connell. 2014. Ownership of Intellectual Property and Corporate Taxation, Journal of Public Economics, Volume 112, Pages $12-23$.

Grubert, Harry. 1998. Taxes and the Division of Foreign Operating Income among Royalties, Interest, Dividends and Retained Earnings, Journal of Public Economics, 68, issue 2, p. 269-290.

. 2003. Intangible Income, Intercompany Transactions, Income Shifting, and the Choice of Location, National Tax Journal, 56(1), 221-242.

2012. Foreign Taxes and the Growing Share of U.S. Multinational Company Income Abroad: Profits, Not Sales, Are Being Globalized, National Tax Journal, 65:2, pp. 247-81

Guvenen, Fatih, Raymond J. Mataloni, Jr., Dylan G. Rassier, and Kim J. Ruhl. 2017. Offshore Profit Shifting and Domestic Productivity Measurement, NBER Working Papers 23324, National Bureau of Economic Research 
Hartman, David G. 1985. Tax Policy and Foreign Direct Investment, Journal of Public Economics, 26 (1), 107 - 121.

Hardeck, Inga and Patrick Uwe Wittenstein. 2017. Assessing the Tax Benefits of Hybrid Arrangements - Evidence from the Luxembourg Leaks. Available at SSRN: https://ssrn.com/abstract=2709629 or http://dx.doi.org/10.2139/ssrn.2709629

Hasegawa, Makoto and Kozo Kiyota. 2017. The Effect of Moving to a Territorial Tax System on Profit Repatriation: Evidence from Japan, Journal of Public Economics, vol. 153(C), pages 92-110.

Hebous, Shafik and Niels Johannesen. 2015. "At Your Service! The Role of Tax Havens in International Trade with Services," CESifo Working Paper Series 5414, CESifo Group Munich

Heckmeyer, Jost and Michael Overesch. 2017. Multinationals' Profit Response to Tax Differentials: Effect Size and Shifting Channels, Canadian Journal of Economics, forthcoming

Hines, J. 2014. How Serious a Problem is Base Erosion and Profit Shifting? Canadian Tax Journal 62(2), p. 443-53. and E. Rice. 1994. Fiscal Paradise: Foreign Tax Havens and American Business, Quarterly Journal of Economics, 109, 149-82.

and R.G. Hubbard. 1990. "Coming Home to America: Dividend Repatriations by US Multinationals", in A. Razin and J. Slemrod. Taxation in the Global Economy, Chicago: University of Chicago Press, 161-200.

Huizinga, Harry, Johannes Voget, and Wolf Wagner. 2009. International Taxation and Takeover Premiums in Cross-border M\&As, CEPR Discussion Papers 7182, C.E.P.R. Discussion Papers. and Laeven, Luc. 2008. International profit shifting within multinationals: A multicountry perspective, Journal of Public Economics, 92, issue 5-6, p. 1164-1182 , Luc Laeven and Gaëtan Nicodème. 2008. Capital structure and international debt shifting, Journal of Financial Economics, Volume 88, Issue 1, Pages 80-118

IMF. 2014. Spillover in International Corporate Taxation, IMF Policy Report, Washington DC.

The Platform for Collaboration on Tax. 2018. The Taxation of Offshore Indirect Transfers A Toolkit, Discussion Draft Version 2, available at: http://www.imf.org/en/News/Articles/2018/07/13/pr18297-the-platform-forcollaboration-on-tax-invites-final 
The Joint Committee on Taxation. 2015. Background, Summary, And Implications of The OECD/G20 Base Erosion And Profit Shifting Project, Washington DC

Johannesen, Niels. 2014. Tax Avoidance with Cross-Border Hybrid Instruments, Journal of Public Economics, Volume 112, 2014, Pages 40-52

, Thomas Tørsløv, and Ludvig Wier. 2016. Are Less Developed Countries more exposed to Multinational Tax Avoidance? Method and Evidence from Micro-Data, WIDER Working Paper Series 010, World Institute for Development Economic Research (UNU-WIDER).

Jun, J. 1994. How taxation affects foreign direct investment (country-specific evidence), Policy Research Working Paper 1307, Washington DC: World Bank.

Karkinsky, Tom and Nadine Riedel. 2012. Corporate Taxation and the Choice of Patent Location within Multinational Firms, Journal of International Economics, 88, issue 1, p. 176-185

Klassen, Kenneth J. and Stacie Kelley Laplante. 2012a. Are U.S. Multinational Corporations Becoming More Aggressive Income Shifters? Journal of Accounting Research, 50: 1245-1285.

and Stacie Kelley Laplante. 2012b. The Effect of Foreign Reinvestment and Financial Reporting Incentives on Cross-Jurisdictional Income Shifting. Contemporary Accounting Research, Vol. 29, No. 3, pp. 928-955.

Kopits, G.F. 1972. Dividend Remittance Behavior within the International Firm: a CrossCountry Analysis, Review of Economics and Statistics, 54, 339-42.

1976. Intra-Firm Royalties crossing Frontiers and Transfer Pricing Behavior, Economic Journal, 86, 791-805.

Liu, Li, Tim Schmidt-Eisenlhor and Dongxian Guo. 2017. International Tax Avoidance and Transfer Mispricing: Evidence from Linked Tax-Trade Statistics in the UK, Oxford Centre for Business Taxation Working Paper 17/02.

Lohse, Theresa, Nadine Riedel, and Christoph Spengel. 2012. The Increasing Importance of Transfer Pricing Regulations - a Worldwide Overview, Working Papers 1227, Oxford University Centre for Business Taxation.

Loretz, Simon and S. Mokkas. 2015. Evidence for Profit Shifting with Tax-sensitive Capital Stocks, FinanzArchiv: Public Finance Analysis, 71, issue 1, p. 1-36.

Maffini, G. and S. Mokkas. 2011, Profit Shifting and Measured Productivity of Multinational Firms. Oxford Bulletin of Economics and Statistics, 73: 1-20. 
Markle, K. 2016, A Comparison of the Tax-Motivated Income Shifting of Multinationals in Territorial and Worldwide Countries. Contemporary Accounting Research, 33: 7-43.

Matheson, Thornton, Victoria J. Perry and Chandara Veung. 2014. Territorial versus Worldwide Corporate Taxation: Implications for Developing Countries," in "Taxation and Development: The Weakest Link?" Cheltenham, UK: Edward Elgar Publishing, Inc.

Michael McDonald. 2008. Income Shifting from Transfer Pricing: Further Evidence from Tax Return Data. Office of Tax Analysis Occasional Papers. U.S. Department of the Treasury.

Merz, Julia and Michael Overesch. 2017. Profit shifting and tax response of multinational banks, Journal of Banking \& Finance, Volume 78, Pages 57-68.

Mills, Lillian F. and Newberry, Kaye J. 2004. Do Foreign Multinationals' Tax Incentives Influence Their U.S. Income Reporting and Debt Policy?, National Tax Journal, 57:1, pp. 89-107.

Mintz, Jack and Alfons J. Weichenrieder. 2005. Taxation and the Financial Structure of German Outbound FDI, CESifo Working Paper Series 1612, CESifo Group Munich. and Alfons J. Weichenrieder. 2010. The Indirect Side of Direct Investment: Multinational Company Finance and Taxation, MIT Press Books, The MIT Press, Edition 1, Volume 1, January.

Newlon, T.S. 1987. Tax Policy and Multinational Firms' Financial Policy and Investment Decisions, PhD Dissertation, Princeton University.

OECD. 2015. 2015 Final Reports, OECD/G20 Base Erosion and Profit Shifting Project, OECD Publishing, Paris.

Overesch, Michael and Georg Wamser. 2010. Corporate Tax Planning and ThinCapitalization Rules: Evidence from a Quasi-Experiment, Applied Economics, 42, issue 5, p. 563-573.

Riedel, Nadine, Thereza Zinn, and Patricia Hofmann. 2015. Do Transfer Pricing Laws Limit International Income Shifting? Evidence from European Multinationals, Discussion Paper, University of Bochum.

Rousslang, Donald. 1997. International income shifting by US multinational corporations, Applied Economics, vol. 29(7), pages 925-934.

Ruf, M. and A.J. Weichenrieder. 2012. The taxation of passive foreign investment: lessons from German experience. Canadian Journal of Economics, 45: 1504-1528. 
Saunders-Scott, Molly J., 2015. Substitution Across Methods of Profit Shifting, National Tax Journal, 68, issue 4, p. 1099-1120.

Schindler, Dirk, Jarle Møen, Guttorm Schjelderup, and Julia Tropina. 2013. International Debt Shifting: Do Multinationals Shift Internal or External Debt? Annual Conference: Competition Policy and Regulation in a Global Economic Order 79749, German Economic Association.

Schwarz. 2009. Tax-Avoidance Strategies of American Multinationals: An Empirical Analysis, Managerial and Decision Economics, 30: 539-549 (2009).

Slemrod, J., 1990. "Tax Effects on Foreign Direct Investment in the United States: Evidence from a Cross-Country Comparison", in A. Razin and J. Slemrod eds. Taxation in the Global Economy, Chicago: University of Chicago Press, 79-117.

Stanley, T.D., Hristos Doucouliagos, Margaret Giles, Jost H. Heckemeyer, Robert J. Johnston, Patrice Laroche, Jon P. Nelson, Martin Paldam, Jacques Poot, Geoff Pugh, Randall S. Rosenberger and Katja Rost. 2013. Meta-analysis of Economics Research Reporting Guidelines._Journal of Economic Surveys Vol. 27, No. 2, pp. 390-394

Tørsløv, Thomas R., Ludvig S. Wier and Gabriel Zucman. 2018. The Missing Profits of Nations, NBER Working Paper Series No. 24701.

UNCTAD. 2013. Global Value Chains: Investment and Trade for Development, World Investment Report 2013.

Voget, Johannes. 2011. Relocation of Headquarters and International Taxation, Journal of Public Economics, Volume 95, Issues 9-10, 2011, Pages 1067-1081.

Weichenrieder, Alfons J., 1996. Anti-Tax-Avoidance Provisions and the Size of Foreign Direct Investment, International Tax and Public Finance, vol. 3(1), pages 67-81. . 2009. Profit Shifting in the EU: Evidence from Germany, International Tax and Public Finance, June 2009, v. 16 (3), pp. 281-97.

Wooldridge, Jeffrey. 2010. Econometric Analysis of Cross Section and Panel Data, Second Edition. MIT Press.

Weyzig, Francis. 2013. Tax Treaty Shopping: Structural Determinants of Foreign Direct Investment Routed through the Netherlands, International Tax and Public Finance, 20, issue 6, p. 910-937.

Zinn, Theresa and Nadine Riedel. 2013. "Do Transfer Pricing Laws Limit International Income Shifting? Evidence from European Multinationals," CESifo Working Paper Series 4404, CESifo Group Munich. 
Zucman, Gabriel. 2014. Taxing across Borders: Tracking Personal Wealth and Corporate Profits. Journal of Economic Perspectives, 28 (4). pp. 121-148. 


\section{Appendix 1. Descriptive Overview of Included Studies}

\begin{tabular}{|c|c|c|c|c|c|c|}
\hline Study & $\begin{array}{l}\text { Total } \\
\text { estimates }\end{array}$ & $\begin{array}{c}\text { Conditional } \\
\text { estimates }\end{array}$ & Mean & Median & Min & Max \\
\hline Azemar (2010) & 3 & 2 & 2.54 & 1.02 & 0.99 & 5.62 \\
\hline Barrios and d'Andria (2016) & 8 & 0 & 0.49 & 0.37 & 0.23 & 0.95 \\
\hline Becker and Riedel (2012) & 3 & 0 & 0.76 & 0.73 & 0.71 & 0.84 \\
\hline Beer and Loeprick (2015) & 19 & 18 & 0.85 & 0.90 & 0.39 & 1.28 \\
\hline Beer and Loeprick (2017) & 31 & 31 & 1.77 & 1.69 & 0.61 & 2.91 \\
\hline Beuselinck et. al (2016) & 25 & 7 & 3.60 & 1.60 & -3.25 & 12.54 \\
\hline Blouin et. al (2012) & 1 & 0 & 0.54 & 0.54 & 0.54 & 0.54 \\
\hline Castillo and Lopez (2016) & 1 & 0 & 2.08 & 2.08 & 2.08 & 2.08 \\
\hline Clausing (2009) & 5 & 0 & 3.76 & 3.65 & 1.05 & 5.52 \\
\hline Clausing (2016) & 8 & 0 & 2.92 & 2.84 & 1.85 & 4.61 \\
\hline Collins et al (1998) & 1 & 1 & 0.32 & 0.32 & 0.32 & 0.32 \\
\hline Crivelli et al. (2016) & 20 & 1 & 2.02 & 1.33 & 0.17 & 5.59 \\
\hline De Simone (2015) & 9 & 9 & 0.83 & 0.91 & 0.25 & 1.29 \\
\hline De Simone et. al (2014) & 2 & 0 & 1.00 & 1.00 & 0.66 & 1.34 \\
\hline Dharmapala and Riedel (2013) & 1 & 0 & 1.13 & 1.13 & 1.13 & 1.13 \\
\hline Dischinger (2010) & 16 & 4 & 1.60 & 1.54 & 0.72 & 3.32 \\
\hline Dischinger and Riedel (2011) & 4 & 0 & 3.20 & 3.18 & 2.14 & 4.29 \\
\hline Dischinger et al. (2014) & 28 & 4 & 0.91 & 0.68 & -0.51 & 1.82 \\
\hline Dowd et al. (2017) & 10 & 4 & 0.81 & 0.84 & -0.03 & 1.44 \\
\hline Grubert (2003) & 5 & 4 & 0.75 & 0.85 & 0.33 & 1.05 \\
\hline Grubert (2012) & 18 & 6 & 1.31 & 1.20 & 0.63 & 2.31 \\
\hline Hines and Rice (1994) & 6 & 0 & 5.16 & 3.31 & 2.25 & 12.99 \\
\hline Huizinga and Laeven (2008) & 27 & 1 & 1.25 & 0.98 & 0.49 & 3.71 \\
\hline Johannessen et al. (2017) & 8 & 0 & 0.69 & 0.75 & 0.12 & 1.31 \\
\hline Klassen and Laplante (2012a) & 9 & 9 & 0.60 & 0.44 & 0.17 & 1.19 \\
\hline Klassen and Laplante (2012b) & 8 & 8 & 0.91 & 0.88 & 0.69 & 1.28 \\
\hline Loretz and Mokkas (2015) & 12 & 0 & -0.07 & -0.11 & -0.79 & 0.80 \\
\hline Maffini and Mokkas (2011) & 22 & 0 & 1.21 & 1.03 & 0.23 & 4.87 \\
\hline Markle (2016) & 12 & 3 & 0.95 & 0.92 & 0.34 & 1.71 \\
\hline McDonald (2008) & 20 & 14 & 1.26 & 1.36 & 0.73 & 1.65 \\
\hline Merz and Overesch (2017) & 13 & 12 & 2.05 & 2.18 & 0.23 & 3.00 \\
\hline Mills and Newberry (2004) & 4 & 0 & 1.94 & 1.03 & -1.16 & 6.86 \\
\hline Riedel et al. (2015) & 14 & 14 & 0.71 & 0.59 & 0.29 & 1.79 \\
\hline Rousslang (1997) & 12 & 0 & 4.74 & 5.00 & 3.63 & 5.63 \\
\hline Saunder-Scott (2016) & 2 & 0 & 0.87 & 0.87 & 0.66 & 1.08 \\
\hline Schwarz (2009) & 9 & 0 & 1.78 & 2.03 & -1.33 & 3.62 \\
\hline Weichenrieder (2009) & 6 & 4 & 0.94 & 0.91 & 0.79 & 1.25 \\
\hline
\end{tabular}




\section{Appendix 2. Comparison to Heckmeyer and Overesch (2017)}

Table 3 column 4 restricts the sample to estimates that were included in $\mathrm{HO}$, and reports a consensus estimate of around 1 . The measured sensitivity to international tax differentials exceeds HO's estimate by 25 percent, which could be due to (i) a different estimation strategy, (ii) a different baseline sample, or (iii) the inclusion of different control variables. We examine each one in turn in Table A.1, by using the $\mathrm{HO}$ assumptions and then addressing each of these possibilities in turn. For (ii) and (iii), however, we also show GLS estimates.

Columns 1 and 2 of Table A.1 examine the importance of different estimation strategies, by using the same sample and specification in HO (2017). Column 1 reports a consensus estimate of 0.797 using WLS, which is very similar to the value of 0.786 found by HO. ${ }^{33}$ Column 2 reports the GLS consensus estimate, which increases to 0.997. The difference in estimates is not surprising, given that around 60 percent of the residual variation in primary estimates is due to differences between studies.

Table A.1. Comparison to HO

\begin{tabular}{|c|c|c|c|c|c|c|}
\hline \multicolumn{7}{|c|}{ Dependent variable: semi-elasticity of reported profit (no winsorizing) } \\
\hline \multirow[t]{2}{*}{ Differences in: } & \multicolumn{2}{|c|}{ Estimation Strategy } & \multicolumn{2}{|c|}{ Sample } & \multicolumn{2}{|c|}{ Controls } \\
\hline & $\begin{array}{l}\text { WLS } \\
\text { (1) }\end{array}$ & $\begin{array}{c}\text { GLS } \\
\text { (2) }\end{array}$ & $\begin{array}{l}\text { WLS } \\
\text { (3) }\end{array}$ & $\begin{array}{c}\text { GLS } \\
\text { (4) }\end{array}$ & $\begin{array}{c}\text { WLS } \\
(5)\end{array}$ & $\begin{array}{c}\text { GLS } \\
(6)\end{array}$ \\
\hline \multirow[t]{2}{*}{ Constant } & $0.797 * * *$ & $0.997 * * *$ & $0.499 * * *$ & $0.816^{* * * *}$ & $0.759 * * *$ & $0.963 * * *$ \\
\hline & [0.116] & [0.248] & [0.119] & [0.161] & [0.118] & [0.294] \\
\hline \multirow[t]{2}{*}{ EBIT } & 0.061 & $-0.263 * *$ & 0.117 & -0.012 & 0.115 & $-0.267 * *$ \\
\hline & [0.132] & [0.116] & {$[0.079]$} & [0.058] & [0.166] & {$[0.100]$} \\
\hline \multirow[t]{2}{*}{ Debt } & -0.346 & $-0.302 * *$ & $-0.343^{*}$ & -0.031 & -0.348 & $-0.259 * *$ \\
\hline & [0.402] & {$[0.126]$} & [0.190] & [0.195] & [0.386] & {$[0.115]$} \\
\hline \multirow[t]{2}{*}{ After Tax } & 0.488 & 0.312 & $0.792 * * *$ & 0.186 & 0.516 & 0.405 \\
\hline & [0.492] & {$[0.258]$} & [0.193] & {$[0.248]$} & [0.709] & [0.359] \\
\hline \multirow[t]{2}{*}{ zMidyear } & 0.014 & $0.055^{*}$ & $0.020 * * *$ & $0.034 * * *$ & 0.02 & $0.060^{*}$ \\
\hline & {$[0.029]$} & [0.033] & [0.007] & {$[0.008]$} & [0.027] & [0.033] \\
\hline \multirow[t]{2}{*}{ Aggregate Data } & -0.055 & $1.459^{*}$ & 0.31 & $1.430 * * *$ & 0.037 & $1.300^{*}$ \\
\hline & [0.473] & [0.749] & [0.479] & {$[0.518]$} & [0.708] & {$[0.724]$} \\
\hline \multirow[t]{2}{*}{ Single Rate } & -0.049 & -0.414 & $0.266 * *$ & -0.204 & -0.054 & -0.396 \\
\hline & {$[0.150]$} & {$[0.356]$} & {$[0.101]$} & [0.146] & {$[0.160]$} & {$[0.366]$} \\
\hline \multirow[t]{2}{*}{ No Time } & -0.117 & -0.136 & -0.014 & 0.02 & -0.049 & -0.08 \\
\hline & {$[0.433]$} & [0.253] & [0.106] & [0.089] & [0.411] & {$[0.237]$} \\
\hline \multirow[t]{2}{*}{ No Firm } & 0.091 & 0.583 & $0.301 *$ & 0.083 & 0.083 & 0.617 \\
\hline & {$[0.238]$} & [0.702] & [0.163] & [0.091] & {$[0.214]$} & [0.723] \\
\hline \multirow[t]{2}{*}{ No Country FE } & 0.119 & 0.244 & -0.156 & $0.500 * * *$ & 0.042 & 0.091 \\
\hline & [0.340] & {$[0.671]$} & {$[0.206]$} & [0.119] & {$[0.428]$} & {$[0.706]$} \\
\hline \multirow[t]{2}{*}{ Ratio } & & & & & 0.022 & -0.096 \\
\hline & & & & & [0.366] & {$[0.457]$} \\
\hline
\end{tabular}

${ }^{33}$ The coefficient estimates on the indicators are not directly comparable, as we defined our baseline differently. However, none of the coefficient estimates is statistically significant at conventional levels. 
No Real Control

Group

variance/Total

variance

Observations
0.263

[0.325]

$0.715 * * *$

[0.127]

0.714

208

Notes: $* * *, * *$, and $*$ depict significance at the $1 \%, 5 \%$, and $10 \%$ level, respectively. Fully robust standard errors in square brackets.

Columns 3 and 4 check the effect of using different samples. Column 3 estimates HO's preferred specification with WLS in our broader sample, and finds a much smaller consensus estimate of 0.499. Column 4 reports the GLS results under the same specification and sample, which increases the consensus estimate to roughly 0.816 . Interestingly, the coefficient for the Z-midyear variable also becomes significant at the one percent level when using the larger sample, suggesting the increasing trend of the consensus semi-elasticity estimate is only captured in the broader sample that include more studies and primary estimates. The insight is important for the policy debate on profit shifting and for the calibration of economic models that account for tax avoidance.

Finally, columns 5 and 6 examine the importance of specification bias. In our baseline regressions, we control for characteristics of primary studies that explain measured effects in our sample, which were not included in HO. Column 5 adds the indicators Ratio and No Real Control in HO's preferred specification and uses the HO sample. The estimated constant remains very close to the $\mathrm{HO}$ estimate and the indicator variables do not explain variation in primary estimates. Column 6 repeats estimation with GLS. While the coefficient on Ratio remains insignificant, the indicator No Real Control now systematically explains differences in primary estimates. The consensus estimate is, with a value of 0.96 , slightly smaller than the GLS estimate presented in column 2 of Table 2 when neglecting these indicators.

In sum, the differences in estimation strategy, sample and control variables cause differences between our findings and HO. The broader sample and the additional control for studyspecific characteristics reduce estimated semi-elasticities, while the use of GLS seems to raise them. A major difference between these estimation methods is that reported standard errors are more important in determining the weights used in the WLS approach. Accordingly, a positive correlation between standard errors and estimated semi-elasticities would explain why WLS yields smaller average semi-elasticities than GLS. 


\section{Appendix 3. Estimating Tax-Motivated Profit Shifting: Theoretical Underpinnings}

We use a simple model based on Huizinga and Laeven (2008) to set out the effect of taxes on cross-border profit shifting. A representative MNC operates in $n$ countries, with the parent residing in country $p$. The corporate tax base in country $i$ is reported profit $\pi_{i}$, which is the sum of true earnings $\left(B_{i}\right)$ and shifted income $\left(S_{i}\right)$. The latter can be positive or negative and is set to minimize the global tax obligation of the MNC group. Profit shifting is costly, however. When marginal concealment costs increase proportionally with the ratio of shifted to true profit, total shifting costs in country $i$ are given by $\frac{\gamma}{2} \frac{\left(S_{i}\right)^{2}}{B_{i}}$ with $\gamma$ the factor of proportionality. The MNC relocates reported profit to maximize its worldwide after-tax income, subject to the constraint that profit shifting does not generate additional income $\sum_{i=1}^{n} S_{i} \leq 0$. The corresponding Lagrangian is

$$
L=\sum_{i=1}^{n}\left[\left(1-\tau_{i}\right)\left(B_{i}+S_{i}\right)-\frac{\gamma}{2} \frac{\left(S_{i}\right)^{2}}{B_{i}}\right]-\lambda \sum_{i=1}^{n} S_{i},
$$

where $\lambda$ is the shadow value of profit shifting, and $\tau_{i}$ is the statutory corporate tax rate in country $i$. The first order condition with respect to $S_{i}$ requires that:

$$
\left(1-\tau_{i}-\gamma \frac{S_{i}}{B_{i}}\right)-\lambda=0 \text {, for all } i,
$$

so that the marginal tax benefits of income reallocation equals the marginal concealment cost. Using the requirement that the sum of shifted income equals zero, we obtain the optimal profit shifting into country $i$ :

$$
S_{i}=\left(\frac{B_{i}}{\gamma}\right) \frac{\sum_{k \neq i}^{n} B_{k}\left(\tau_{k}-\tau_{i}\right)}{\sum_{k=1}^{n} B_{k}},
$$

or more generally,

$$
S=B \varepsilon(\tau-W \tau)
$$

Where $s, B$, and $\tau$ are vectors in $i=1 \ldots n, \tau$ is the vector of relevant tax rates for the MNC group outside country $i, W$ is a weighting matrix, and the parameter $\varepsilon$, defined as $-1 / \gamma$, is negative. The weights in $W$ are determined by the true earnings $B$.

As an alternative, Crivelli et al. (2016) assume that the cost of profit shifting is unrelated to the true profit reported in a particular country, to accommodate circumstances that significant profit are shifted into a tax haven without substantial earnings. We explore the implications of this alternative assumption by specifying the cost of shifting as by $\frac{\gamma}{2}\left(S_{i}\right)^{2}$, i.e. independent of true earnings. The vector of optimal shifting is now given by:

$$
S=B \varepsilon(\tau-\bar{\tau}),
$$


where $\overline{\boldsymbol{\tau}}$ is the un-weighted average tax rate.

The relationships in (A.4) and (A.4') summarize three simple and intuitive results. First, the direction of profit shifting depends on relative statutory tax rates, i.e. the difference between a host country's statutory tax rate and a weighted or unweighted average of corporate tax rates in all countries where the MNC operates. When a host country's tax rate is above average $((\tau-W \tau)>0$ or $(\tau-\overline{\boldsymbol{\tau}})>0)$, profit shifting reduces the domestic tax base $(S<$ $0)$. Second, the magnitude of shifted income can be proportional to true earnings $B$ or independent of it, depending on the nature of the concealment costs. Third, the tax sensitivity of reported profit is inversely related to the shifting cost parameter $\gamma$, i.e. increasing concealments costs dampen the amount of profit reallocation.

Note that, while cross-border profit shifting does not change the total income of a MNC ( $\left.\sum_{i=1}^{n} S_{i}=0\right)$, it does lead to losses in the total tax revenue globally: $\left(\sum_{i=1}^{n} \tau_{i} S_{i}<0\right)$. In our analysis below, we will assess this revenue loss.

Much of the empirical work on profit shifting centers around identification of $\varepsilon$. The theoretical model provides guidance in this respect. Substituting the optimal amount of income shifting in the definition of reported profit, $\pi_{i}=B_{i}+S_{i}$, and taking a log-linear approximation gives:

$$
\log \left(\pi_{i}\right)=\log B_{i}+\varepsilon(\tau-W \boldsymbol{\tau})
$$

whereby $W \boldsymbol{\tau}$ would be replaced by $\overline{\boldsymbol{\tau}}$ if (4') were used. Eq. (5) shows that the semi-elasticity of reported profit with respect to international tax differentials is directly related to unobservable concealment costs. Once $\varepsilon$ is known, eq. (5) provides an estimate of the average base change of an affiliate. This is proportional to the revenue effect from profit shifting for a single country.

The shifting cost parameter $\gamma$ plays a key role in determining the tax elasticity (since $\varepsilon \equiv$ $-\frac{1}{\gamma}$ ). It could vary across MNCs of different operating scale or industry structure, as well as between countries, reflecting the country-specific enforcement environment and the tax administrative capacity. Conceivably, for every bilateral combination of countries $i$ and $j$ there is a different shifting cost parameter $\gamma_{i j}$. At the group level, $\gamma$ is likely to be lower for MNCs with more affiliates in countries with lax enforcement or weaker administrative capacity. Moreover, $\gamma$ is likely to be lower for MNCs operating in certain industries for which the arm's length principle is less applicable. The heterogeneity of expected tax responses among different types of MNCs suggest that different empirical studies are likely to report different elasticity estimates. Most empirical studies estimate an average elasticity of all MNCs in the sample. Variation in the elasticity estimates across studies will thus reflect structural differences of the MNCs or countries included in the sample. 